ILA الجمعية المصرية للقر اءة و المعرفة عضو الجمعية الدولية للمعرفة
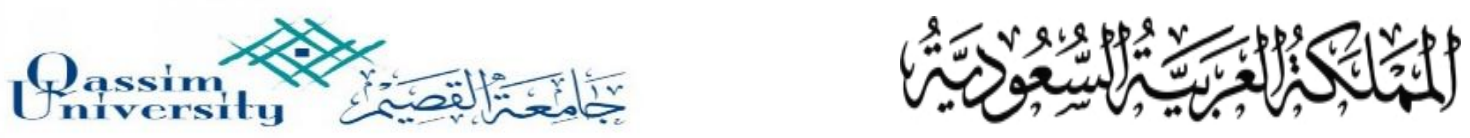

وزارة التعليم

كلية التربية

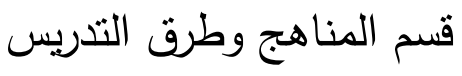

\title{
كفايات التعليم الإكتروني لدى طلاب ومعلمي الأحياء في المرحلة الثانوية في ضوء معايير ISTE
}

$$
\text { الباحث / فايز بن محمد عبدالكريم المهداوي }
$$

سعادة الأستاذ الدكتور/ عبدالرحمن بن محمد النصيان

$$
p_{r \cdot r l}
$$




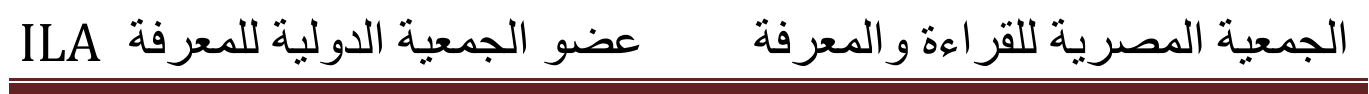




\section{الجمعية المصرية للقر اعة و المعرفة عضو الجمعية الدولية للمعرفة ILA}

\section{مستخلص البحث}

هدف البحث الحالى إلى الكثف عن واقع توافر كفايات التعليم الإكتروني في ضوء معايير الدى لدى طلاب المرحلة الثانوية، والكثف عن واقع توافر كفايات التعليم الإلكتروني في ضوء معايير ISTE لدى معلمي الأحياء للمرحلة الثانوية ، وبناء تصور تلون لتتمية كفايات التعليم الإلكتروني في ضوء معايير ISTE لدى معلمي وطلاب المرحلة الثانوية، وتكونت أدوات البحث من استبانة معايير ISTE للطلاب ، استبانة معايير للمعلمين ، بطاقة المقابلة المفتوحة لتحديد التصور تتمية كفايات التعليم الإلكتروني في ضوء معايير ISTE لاى معلمي وطلاب المرحلة الثانوية ، واستخدم الباحث المنهج الوصفي التحليلي والمنهج الكيفي ( النوعي )، وتكونت عينة البحث من (0 1) طالب من طلاب المرحلة الثانوية العامة وعدد (ع) من معلمى الأحياء بالمرحلة الثانوية.

وتوصلت نتائج البحث إلى أن معرفة المعلم والجهات المسؤولة عن إعداده وتقويمه وبناء البرامج التدريبية المتميزة من خلال الكفايات التدريسية التي تمثل معايير للجودة أيضاً، تدعم الاتجاه العلمي القائل -والذي أثنتته العديد من الدراسات- بأن من لديهم معرفة أكثر

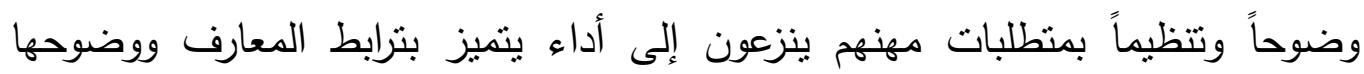
ومعرفة ما هو مطلوب منهم وما ينقصهم من المهارات اللازمة لتطوير ممارساتهم العملية.

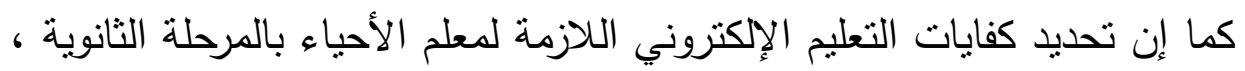
أمرًا ابلغ الأهية ، حيث تعد الكفايات شرطاً أساسياً لتحسين أداء المعلمين وتطوير الإنير مهاراتهم ، وفي ظل تأكيد معظم الدراسات السابقة على أهمية توافر كفايات التعليم الإلكتروني لدى المعلمين عامة ومعلمى الأحياء خاصة ، ظهرت الحاجة إلى إعادة النظر في برامج معلمي العلوم عامة والأحياء خاصة ، لتواكب التغيرات في مجال التعليم

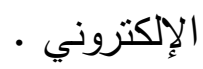




\section{الجمعية المصرية للقر اعة و المعرفة عضو الجمعية الدولية للمعرفة}

من هنا كان تحديد كفايات التعليم الإكتروني اللازمة لتدريس الأحياء لطلاب المرحلة الثانوية هي الخطوة الأولى لتحديد ما لدى المعلمين من معارف ومهارات واتجاهات لاستخدام التعلم الإلكتروني فى تدريس مادة الأحياء وبالتالى بناء البرمجيات الخاصة بذلك ووضع التصورات لهذا الاستخدام. ومن خلال نتائج الملاحظات والمقابلات التى قام بها الباحث يستتتج أهمية إلمام المعلمين بفوائد التعليم الإكتروني ، وايجابيات التعليم الالكتروني ، وأهمية المواطنة والمسئولية الرقمية على الأداب السلوكية في البيئة الرقمية وصياغة قوانين للإدارة في البيئة الرقمية ويصوغ قوانين لإدارة الصف الإلكتروني ويمثلها ، وتشجيع الطلاب من خلال الثناء على اجاباتهم الطلاب ويستخدم التعزيز الرقمي.

\section{المقدمة}

الحمدُ لله وحدَه، والصَّلاة والسَّلام على خير خَلِقه، سيِّدنا محمد خير مَن قرَنَ عِلمَهَ بعَلِّه، وكان خيرَ منفذًا لأوامر الله، منبعًا لهديه، وخير مَن تعلَّم وعلَّم.

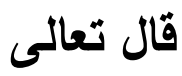

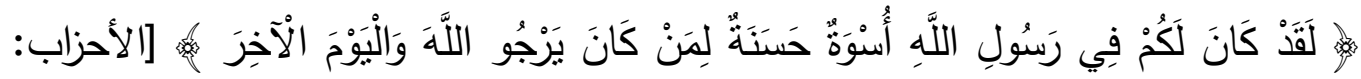
. [Y)

في ضوء رؤية المملكة العربية السعودية •r.r وما تشهده من تطورات ومستجدات في التعليم لبناء جيل جديد يمتلك مهارات وثقافات منتوعة ترتكز على تعليم راسخ، حيث شملت الروية . . . . انطلاقة جديدة إلى تطوير التعليم في جميع المراحل والمناهج والطرق التدريسية والمفاهيم. حيث تعمل رؤية • • • ب بالمملكة العربية السعودية على زيادة الإهتمام بتطوير التعليم منهجاً ومعلماً وطالباً وتدربسًا ومدرسة باعتبار المعلم هو الركيزة الأساسية والمسئول عن تحقيق الأهداف فقد هدفت إلى اعداد المعلم وتطويره المهني بما يتتاسب مع منطلبات 


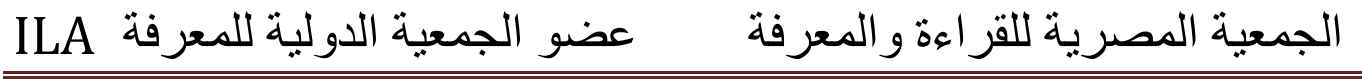

القرن الواحد والعشرين وما يحتاجه من مهارات لمواكبة التطورات الفكرية والصناعية والمعرفية والتكنولوجية ، وذلك باقامة الدورات التدريبية وورش العمل والاطلاع على كل ما ما ماته

$$
\text { هو جديد فى المناهج وطرق التّريس (إيمان العبدلي ، } 9 \text { ( • ب) }
$$

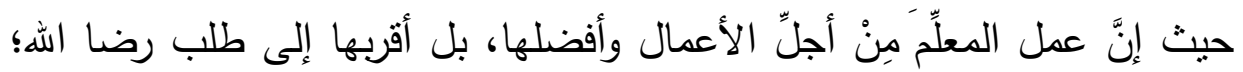

فلقد ورد في الأثر: ((خيركم مَن تعلَّم العِلمَ وعلَّمَه))، ولما للعلم من فضلٍ وأثر فإنَّ المصطفى - عليه السلام - قايض على إطلاق سَراح عددٍ من الأسرى فور إنهاء كلٍّ فئل منهم تعليم عشرةٍ من المسلمين، وذللك بعد انتهاء غزوة بدرٍ •

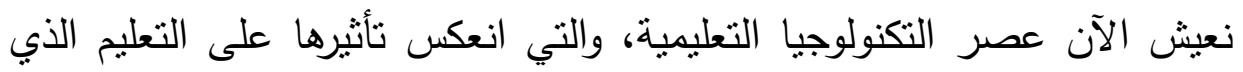
هو طريق التقدم والرقي لأي مجتمع، وإذا كان المعلم يمنل أحد أركان العملية التعليمية،

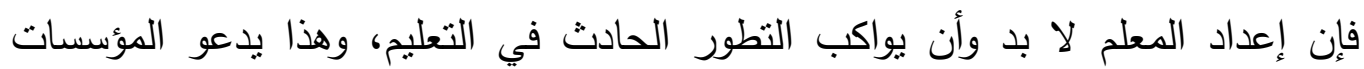
التربوية المهتمة بإعداد المعلم إلى إعادة النظر في برامج إعداد المعلم، والمداخل التربوية

التي يقوم عليها إعداده وإضافة الجديد إليها والعمل على تحسين وتطوير القائم منها. وهناك مداخل كثثرة لإعداد المعلم، منها المدخل التعليمي القائم على الكفايات Competencies وهو مدخل يهدف إلى إعداد المعلم وتأهيله على أسس تربوية ونفسية تهدف إلى رفع مستوى أداء المعلم مهنياً، وتوظيف كفاءته، وتوجيه مهاراته لمساعدة الطلاب على تحقيق أهدافهم.

ومفهوم الكفاية نظر إليه التربويون من زاويتين: شكلها العام ومكوناتها، فالكفاية لها شكلان الكامن منها والظاهر، فالكفاية في شكلها الكامن مفهوم، ومن هنا فهي إمكانية القيام بالععل نتيجة الإلمام بالمهارات والمعارف والمفاهيم والاتجاهات التي تؤهل إلى القيام بالعمل، وفي شكلها الظاهر عملية، ومن هنا فهي الأداء الفعلي للعمل، وهذا لا يعني فقط مجرد إلمام المعلم بالمعارف والمهارات التي تتضمنها الكفاية، بل لابد من أن يكون قادياء 


\section{ILA الجمعية المصرية للقراءة والمعرفة عضو الجمعية الدولية للمعرفة}

على القيام بهذه المهارات وتطبيقها بطرق صحيحة وطبقاً للمعايير المتفق عليها في الأداء.

وتأسيساً على ذلك، ومن خلال الإطلاع على الدراسات السابقة وإجراء المقابلات

الثخصية لطلاب المرحلة الثانوية ومعلمي الأحياء للمرحلة الثانوية والخبرة الثخصية

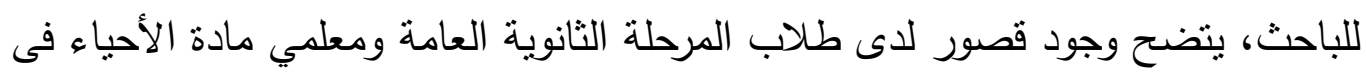
المرحلة الثانوية في كفايات التعليم الإكتروني، ويقترح الباحث إعداد كفايات التعليم الإلكتروني لدى طلاب ومعلمي الأحياء في المرحلة الثانوية. لذا فالإشكالية المطروحة في هذا البحث تتمحور أساساً حول كفايات التعليم

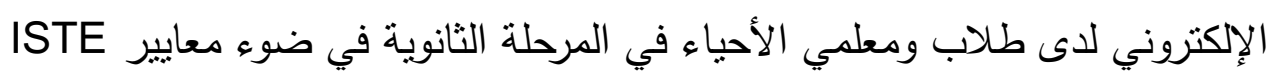
أسئلة البحث الإنئ لاني ا. ما واقع توافر كفايات التعليم الإلكتروني في ضوء معايير ISTE لدى طلاب المرحلة الثانوية ؟ أم r. ما واقع توافر كفايات التعليم الإلكتروني في ضوء معايير ISTE لاى معلمى الأحياء

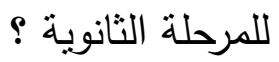
r. ما التصور المقترح لتتمية كفايات التعليم الإكتروني في ضوء معايير ISTE لاى طلاب ومعلمي المرحلة الثانوية ؟

\section{أهداف البحث}

ا. الكثف عن واقع توافر كفايات التعليم الإلكتروني في ضوء معايير ISTE لدى طلاب المرحلة الثانوية. r. الكثف عن واقع توافر كفايات التعليم الإلكتروني في ضوء معايير ISTE لدى

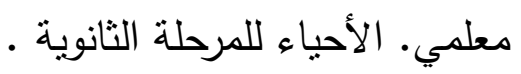
r. بناء تصور لتتمية كفايات التعليم الإلكتروني في ضوء معايير التهيله وطلاب المرحلة الثانوبة. 


\section{ILA الجمعية المصرية للقر اءة والمعرفة عضو الجمعية الدولية للمعرفة}

\section{أدوات البحث}

I. استبانة معايير ISTE للطلاب.

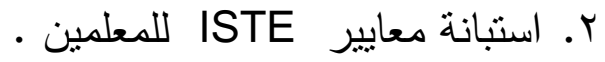

r. بطاقة الدقابلة المفتوحة لتحديد التصور تتمية كفايات التعليم الإلكتروني في ضوء معايير ISTE لدى معلمي وطلاب المرحلة الثانوية.

أهمية البحث : قد يفيد البحث فيما يلي :

الأهمية النظرية :

- - تحديد أكثر كفايات التعليم الإلكتروني نوافق لاى الطلاب.

- يسهم البحث في بناء تصور لتتمية كفايات التعليم الإكتروني لدى المعلمين

والطلاب

- - يُسلط الضوء على جوانب مهمة في تأهيل معلمي العلوم وهو جانب التأهيل المهني - - تحديد كفايات التعليم الإكتروني للمعلمين

- - إبراز دور كفايات التعليم الإلكتروني في المرحلة الثانوية العامة ، والاستفادة منها.

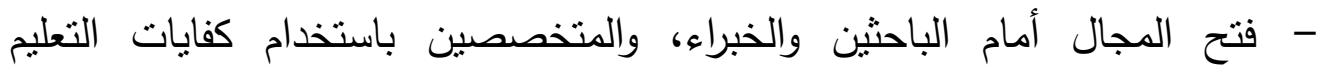
الإكتروني، ومحاولة الاستفادة منها في مجالات التعليم المختلفة.

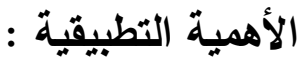

- مخططو البرامج الإلكترونية التعليمية : حيث تقيدهم في تقديم برامج للطلاب فى :

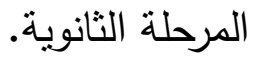

- مخططي مناهج المرحلة الثانوية ومطوريها : حيث تمدهم بقائمة كفايات التعليم

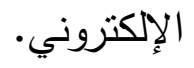

- الباحثون : حيث تتيح الدراسة لدراسات أخرى تهتم بكفايات التعليم الإلكتروني. - تدريب معلىى الأحياء بالمرحلة الثنانوية على كفايات التعليم الإلكتروني. - تدريب طلاب المرحلة الثنانوية على كفايات التعليم الإلكتروني. 


\section{ILA الجمعية المصرية للقر اءة والمعرفة عضو الجمعية الدولية للمعرفة}

- تحديد الاحتياج التنريبي للمعلمين والطلاب.

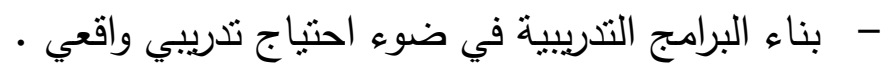

- نطوير برامج إعداد معلم العلوم في ضوء كفائايات عصرية.

- مساعدة مشرفي العلوم على النقييم الموضوعي لأداء معلمي العلوم التدريسي.

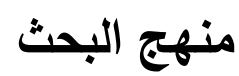

المنهج الكمي : اتبع الباحث المنهج الوصفي النحليلي والذي يهدف وصف الظواهر كما

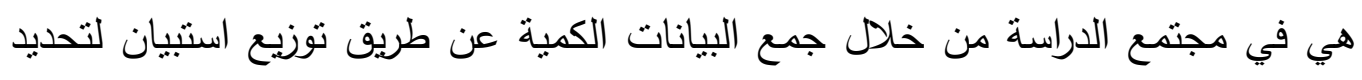

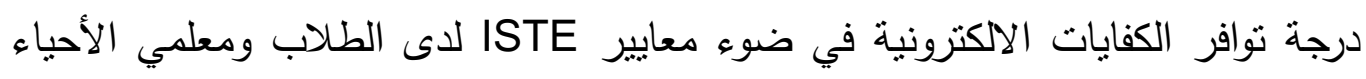

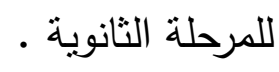
المنهج الكيفي ( النوعي ) : يهدف إلى فهم الظاهرة محل البحث فهمًا عميقًا يصنع معنى

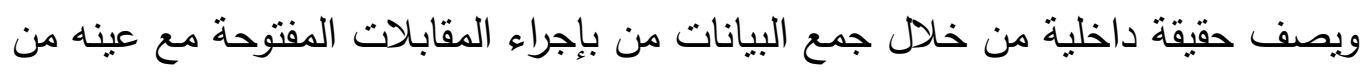

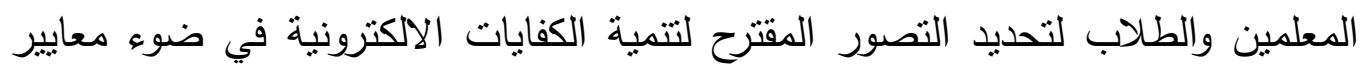

.ISTE

\section{الدراسات السابقة}

ودراسة أفنان عطية الفليت (9 (Y) وهدفت إلى التعرف على مدى فاعلية برنامج

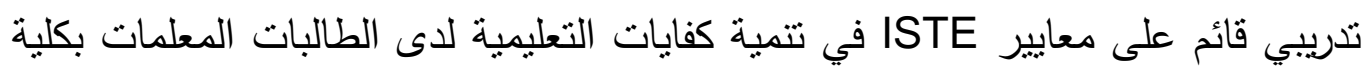

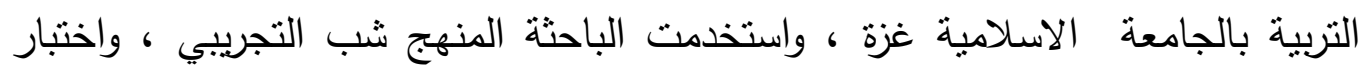

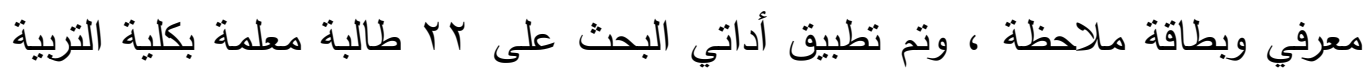

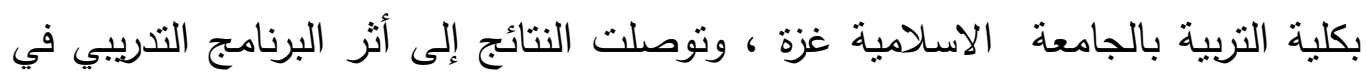
تتمية الكفايات التعليمية لدى الطالبات المعلمات الهيه

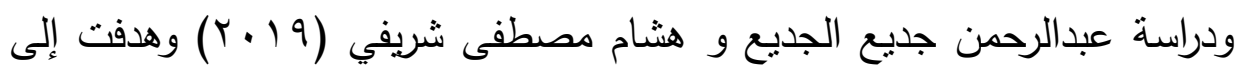
الكثف عن مدى كفاية البرامج التدريبية المقدمة في مراكز التدريب التربوي للمعلمين

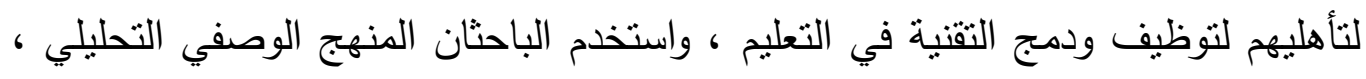




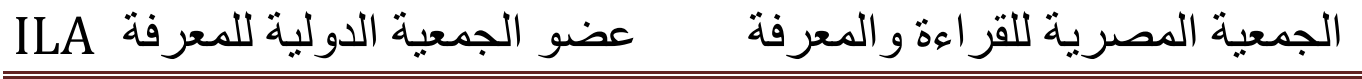

وتم تطبيق البحث على معلى بإدارة التعليم بمحافظة الزلفي بالمملكة العربية السعودية، وتوصلت الدراسة إلى عدم كفاية البرامج التدريبية المقدمة للمعلمين في مجال لبال التقنية التعليمية.

ودراسة حسام الدين السيد تركي بن خالد النافعي(9 19 ـ ب) وهدفت إلى تعرف درجة

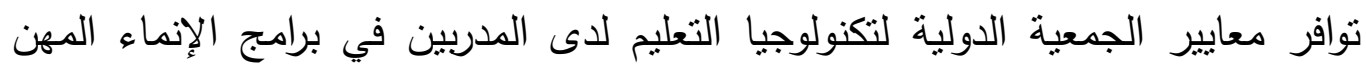
بمدارس التعليم الأساسي ، واستخدم الباحث المنهج الوصفي وتم تطبيق أدوات البحث

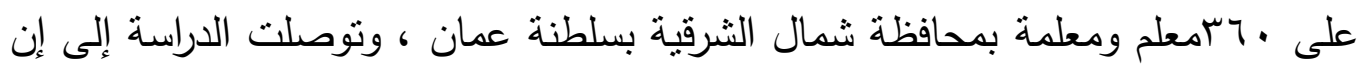
درجة توافر معايير الجمعية الدولية لتكنولوجيا التعليم لدى الددربين في برامج الإنماء المهن بمدارس التعليم الأساسي جاءت يشكل متوسط.

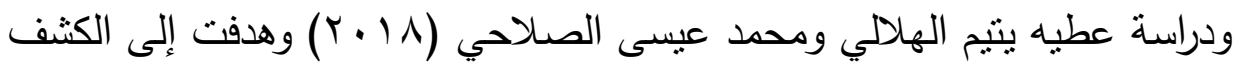
عن واقع كفايات العصر الرقمي لدى معلمي التعليم العام في ضوء معايير الجمعية الدولية للتقنية في التعليم (ISTE 2016) ،واستخدم الباحثان المنهج الوصفي التحليلي

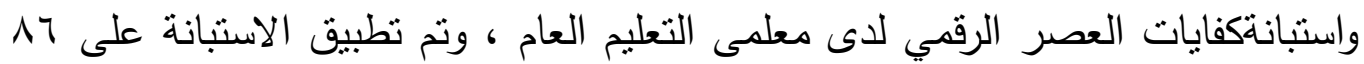

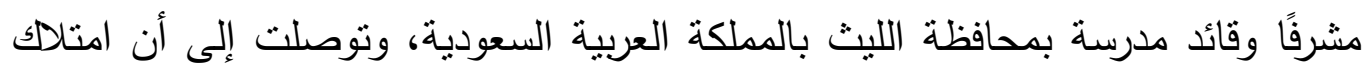
معلمي التعليم العام لكفايات العصر الرقمي بدرجة منوسطة. ودراسة خالد محمد على حسن (Y V P T) وهدفت إلى التعرف على كفايات التعليم الالكتروني لدى معلمي المرحلة الثانوية ، واستخدمت الدراسة المنهج الوصفي واستبانة كفايات التعليم الإلكتروني ، وتم تطبيق أداة البحث على وسا المعلم للمرحلة الثانوية بمديرية أم درمان ، وتوصلت النتائج إلى توافر كفايات التعليم الالكتروني لدى معلمي المرحلة الثانوية بدرجة متوسطة لمرنة ودراسة محمد سلامة الرصاعي (Y. V) وهدفت إلى استقصاء كفايات معلم العلوم في مجال تكنولوجيا المعلومات والاتصالات في التذريس ، واستخدم الباحث استبانة كفايات معلم العلوم وتم تطبيق أداة البحث على سج ا طاب وطالبة بجامعة الحسين بن 


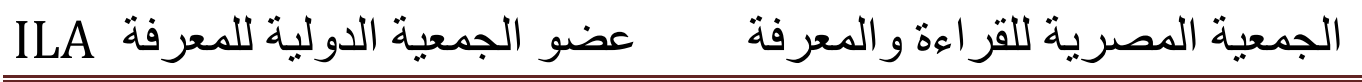

طلال بالأردن، وتوصلت الدراسة إلى أن تراوحت درجة امتلاك عينة الدراسة للكفايات التكنولوجية في مجال التدريس بين درجة منخفضة ومتوسطة. ودراسة رؤى فؤاد محمد باخدلق (ع ( • ب) وهدفت إلى التعرف على درجة امتلاك معلمات الأحياء بالمرحلة الثانوية للكفايات التكنولوجية التعليمية اللازمة لعرض وإنتاج الوسائط المتعددة ، واستخدمت الباحثة المنهج الوصفي، واستبانة الكفايات التكنولوجية التعليمية، وتم تطبيق الدراسة على عينة مكونة من IVV معلمة احياء بالمرحلة الثانوية بإدارة التعليم بالعاصمة المقدة، مكة المكرمة المملكة العربية السعودية، وتوصلت النتائج إلى توافر كفايات التكنولوجية التعليمية اللازمة لعرض الوسائط المتعددة بدرجة عالية و توافر كفايات التكنولوجية التعليمية اللازمة لإنتاج الوسائط المتعددة بدرجة متوسطة. كما هدفت دراسة على زهدى شقور (Y (Y.T) إلى التعرف على واقع الاعداد التربوي للمعلم الفلسطيني في مجال تكنولوجيا التعليم، واستخدمت المنهج الوصفي ، واعتمدت على استبانة واقع الاعداد التربوي للمعلم، وتم تطبيقها على 0؟0 معلم ومعلمة من محافظة نابلس بمدارس دولة فلسطين ، وتوصلت الدراسة إلى وجود تقديرا من قبل عينة الدر اسة لإسهام مساقات تكنولوجيا التعليم في الاعداد المهني للطلبة.

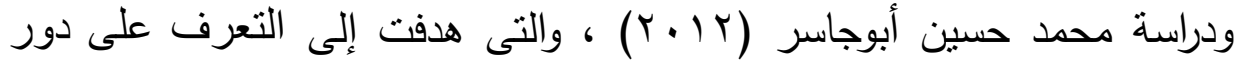
المشرف التربوي في تنمية كفايات تكنولوجيا المعلومات لمعلمي المرحلة الثانوية ، واستخدم الباحث المنهج الوصفي ، واستبانة كفايات تكنولوجيا المعلومات لمعلمى المرحلة الثانوية ، وتكونت عينة البحث من مب معلم ومعلمة للمرحلة الثانوية من مديرية شمال غزة بدولة فلسطين ، وتوصلت الدراسة إلى عدد من النتائج من أبرزها احتلت كفاية تسبير

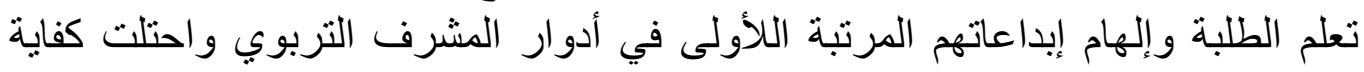
الارتقاء بالمو اطنة و المسؤولية الرقمية كأدنى كفاية يقوم المشرفون بتهية التنميتها.

دراسة حسن على بن دومي (·. • (Y) وهدفت إلى التعرف على درجة امتلاك معلمي العلوم للكفايات التكنولوجية التعليمية ، استخدمت الدراسة المنهج الوصفي ، وتم تطبيق استبانة الكفايات التكنولوجية التعليمية على ب9 معلم ومعلمة من معلمى مديرية 


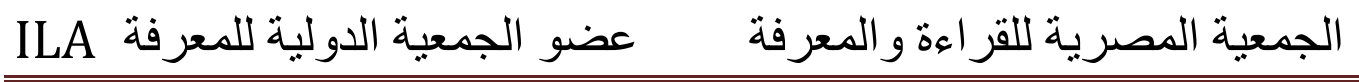

التعليم بمحافظة الكرك، وتوصلت الدرسة إلى عدة نتائج من أهمها امتلاكى معلمي ومعلمات العلوم ل \& \ كفاية بدرجة كبيرة و اب كفاية بدرجة منتوسطة وكفاية واحدة بدرجة منخفضة. إجراعات البحث

ريط مصداقية الدراسة وفق تصنيف ماكسويل (295-p285,paxwell,1992,p ) الصدق الوصفي تم عرض أدوات الدراسة على عدد من المحكمين للنأكد من مناسبة العبارات ووضوحها وانتمائها لمجالات البحث. الصدق التفسيري - فسر الباحث استبيان الطلاب وكذلك استبيان المعلمين حول كفايات التعليم الإلكتروني في ضوء معايير ISTE - تم ارسال استبيان كفايات التعليم الإلكتروني للمعلم ، وتم تفريغها وحصلت على تأييد كبير - تم - تم ارسال استبيان كفايات التعليم الإكتروني للطلاب ، وتم تفريغها وحصلت على تأييد كبير - تمبان الصدق النظري - ترتبط هذه الدراسة بالنظرية البنائية ، فطبقاً لما يراه بياجية ، إن معرفة المعلم

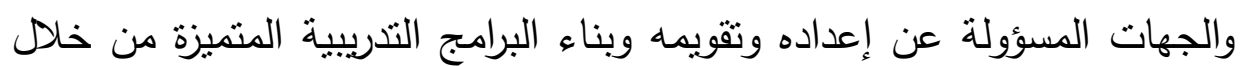
الكفايات التدريسية التي تمثل معايير للجودة أيضاً، تدعم الاتجاه العلمي القائل والذي أثنتته العديد من الدراسات- بأن من لديهم معرفة أكثر وضوحاً وتتظيماً

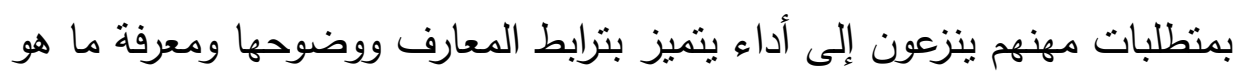
مطلوب منهم وما ينقصهم من المهارات اللازمة لتطوير ممارساتهم العملية. 


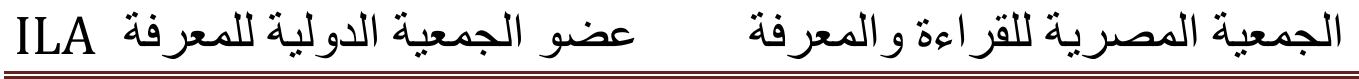

- إن تحديد كفايات التعليم الإلكتروني اللازمة لمعلم الأحياء بالمرحلة الثانوية ، أمرًا

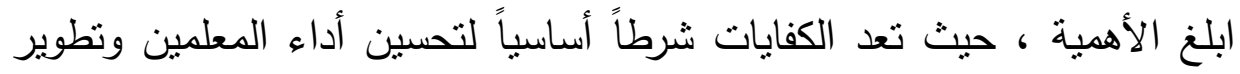
مهاراتهم ، وفي ظل تأكيد معظم الدراسات السابقة على أهمية توافر كفايات التعليم الإلكتروني لاى المعلمين عامة ومعلمى الأحياء خاصة ، ظهرت الحاجة إلى

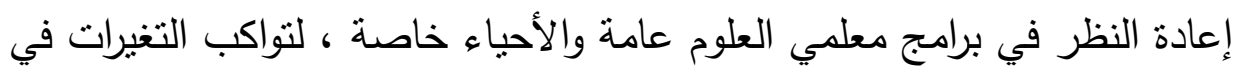

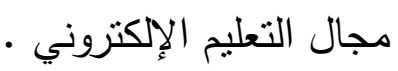
إمكانية التعميم - تهذف الدراسة الحالية إلى الكثف عن واقع نوافر كفايات التعليم الإلكتروني في ضوء معايير ISTE لدى طلاب المرحلة الثانوية. - كما تهدف إلى الكثف عن واقع توافر كفايات التعليم الإلكتروني في ضوء معايير ISTE للدى معلمي. الأحياء للمرحلة الثانوية - بناء تصور لتتمية كفايات التعليم الإكتروني في ضوء معابير ISTE لدى معلمي وطلاب المرحلة الثانوية. الصدق التقويمي - ق قام الباحث في البحث الحالي بوصف وفهم موضوع الدراسة دون تقويمها، والقرب من البيانات والعودة إليها عند كتابة تقرير البحث، وإعداد سجلات مكتوبة عنها ، وفحص بيانات البحث، والتواصل مع المحكمين والمعلمين والطلاب بشأن كقايات مصطلحات البحث التعليم الإلكتروني Competency الكفاية " تلك المقدرة المتكاملة التي تشمل مجمل مفردات المعرفة والمهارات والاتجاهات

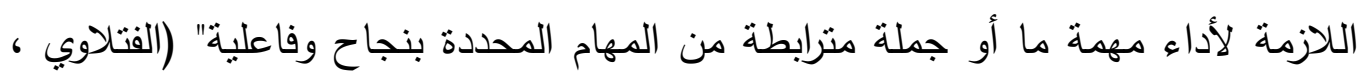
$(r \wedge, r \cdot r$ 


\section{ILA الجمعية المصرية للقر اءة والمعرفة عضو الجمعية الدولية للمعرفة}

\section{E-Learning التعلم الإكتروني}

" طريقة للتعليم باستخدام آليات الاتصال الحديثة من حاسب وشبكاته ووسائطه المتعددة من صوت وصورة ورسومات وآليات بحث ، ومكتبات إلكترونية وكذللك بواوبات

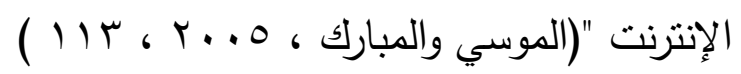

" طريقة استخدام آليات الاتصال الحديثة من حاسب وشبكات ووسائط متعددة من

صوت وصورة ورسومات وآليات ومكتبات إلكترونية في تقديم محتوي إلكتروني ، وتوفير بيئة تعليمية إلكترونية تفاعلية بستخدمها المتعلم في أي وقت ومن أي مكان وبأي سرعة

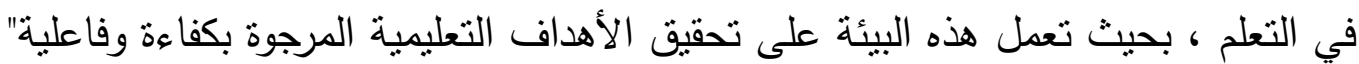

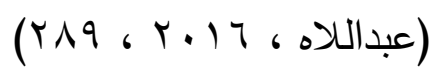

\section{كفايات التعلم الإكتروني E Learning Competencies}

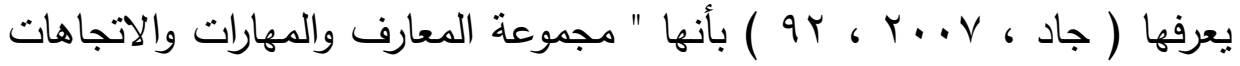
الخاصة بالتعليم الإلكتروني واستخداماته اللازمة في بناء المواقف التعليمية بسهولة ويسر باستخدام الوسائل الإلكترونية لتحقيق الأهداف التربوية" فلسفة البحث

تنطلق المدرسة النوعية التفسيرية من أن الحقيقة متغيرة وليست ثابته وتتغير وتتثكل وتبنى تبعًا لفهم المجموعات البشرية والأفراد، وهي الفلسفة التي بستتد عليها البحث النوعي فالعينة في هذا البحث يتحدثن عن أفكارهم، تجاربهم، ممارساتهم، من منظورهم الخاص مستخدمين الألفاظوالأفعال - والتي يعبر عنها في هذا البحث بالكفايات

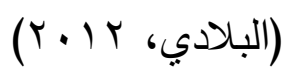

الطبيعة الوجودية الأنطولوجيا ontology أو علم الوجود والتي تعد أحد تفريعات الفلسفة التي تؤكد على حقيقة الوجود من حولنا هل هو مادي أم روحي؟ أو أنه مزيج بينهما.

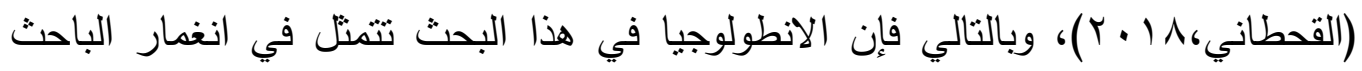
وتفاعله مع المبحوثين فيما يحملون من معان حول الكفايات الالكترونية وهو ما أكدته لـانه 


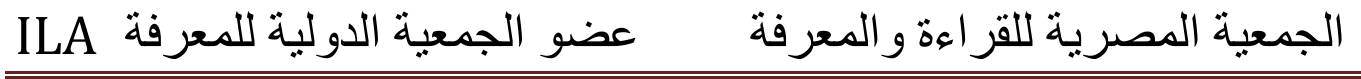

البنائية الاجتماعية التي ترى أن المعرفة تبنى من خلا التفاعل بين أطراف العملية وهو ما يتطلب من الباحث التفاعل من العينة المختارة وفهم وجهات نظرهم حول التصور المقترح لتتميته الكفايات الالكترونية. طبيعة المعرفة الابستمولوجيا epistemology والتي تتمثل في نسق المعتقدات الفلسفية التي تتعلق بما يمكن أن يكون عارف وبما يمكن أن يُعرف (شارلي هيس، باتريشا،

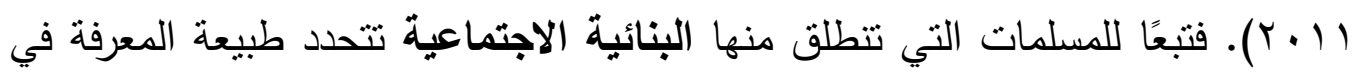
البحث والتي حددها كريس ويل (creswell.2018) في كروتي ( crotty.1998): تتشكل رؤية الفرد للعالم من خلال تفسيره له ولما يحويه، وهو ما دفع الباحث لصياغة أسئلة مفتوحة النهاية ليمكن المبحوثين من الإدلاء بمكنوناتهم حول معوقات تتمية الكفايات الالكترونية ووضع أطر للتصور لتتميتها. إن تفاعل الفرد مع محيطه الاجتماعي بشكل مستمر يشكّل تصوره نحو القضايا

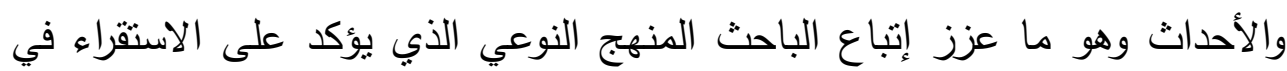
استخلاص الأفكار والتصورات.

ا. إن القضايا الأخلاقية التي يجب أن تؤخذ في الاعتبار عند تخطبط البحث والتي يشار

إليها بالقيم (Axiology). r. وضمن أخلاقيات البحث التزم الباحث بماء بلئي: حرص الباحث على الحصول على الموافقات الرسمية لتطبيق بحثث. حرص الباحث على الحصول على موافقات المبحوثين من المعلمين والطلاب عينة البحث.

أطلاع الباحث المبحوثين على أهداف البحث قبل البدء في جمع المعلومات منهم.

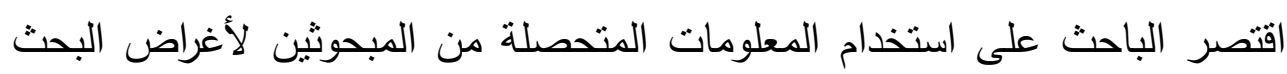
فقط والتأكيد على سريتها كما وضح لهم الأدوار المنوطة بهم في الادلاء بما يمتلكون حيال موضوع البحث. 


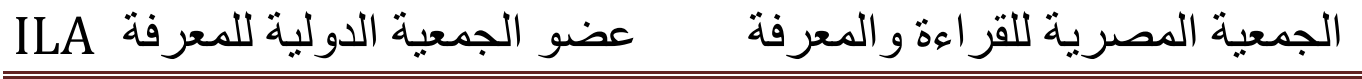

r. الوساطة والتي تمثل العلاقة بين المنتبئ بنتيجة ما والمنبئ به في البحث النوعي، والتي

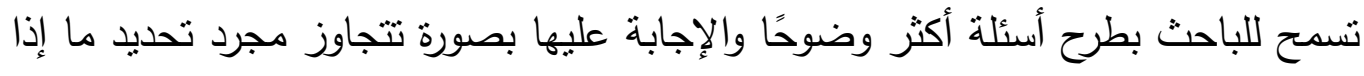
كانت النتيجة ستحدث، كما أنها تتيح للباحث أن يفهر كيف ولماذا يحدث. والتي تجسدت في مقابلة الباحث للمبحوثين والجلوس إليهم وبناء علاقة جيدة معهم.

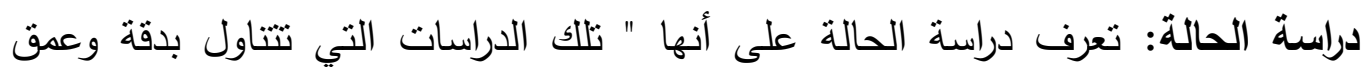
وصف وتحليل وتفسير ظاهرة أو حالة معينة أو موقف محدد بغرض تحديد الظروف التي

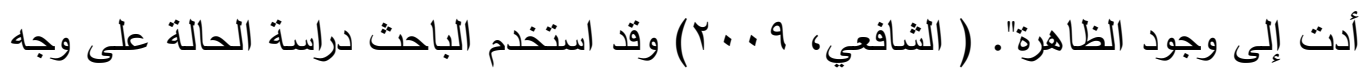
الخصوص لمناسبته للبحث وهدفه ومنطلقاته الانطولوجية، كما أنها تمكن الباحث من الحصول على معلومات وآراء يصعب التحصل عليها من خلال أدوات جمع البيانات الكمية، وانطلاقا من النظرة الابستمولوجية لهذا البحث التي ترى أن المعرفة داخلية الأمر الذي يتطلب سبرها من خلال التفاعل الاجتماعي والغوص في المبحوثين تبعًا للفلسفة البنائية الاجتماعية، وسيتبع الباحث منهجية الدراسة النوعية المتعددة التي تعتمد على جمع البيانات المتعددة والعميقة والثرية من خلال استخدام مصادر متعددة من جمع البيانات.

\section{الإطـار النظـري للبــث}

المفاهيم المعاييز : (Norms) تعد المعايير عبارة عن مستوى محدد من التميز في الأداء أو درجة محددة من الجودة المطلوبة في شيء أو عملية أو أنها أسس كيفية للحكم على درجة التميز المطلوبة

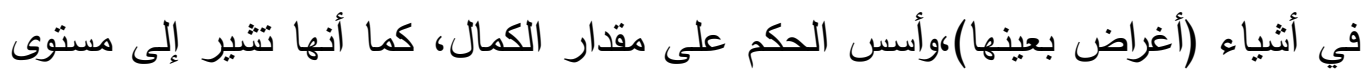

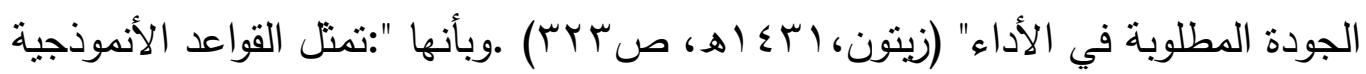
أو الأطر المرجعية أو الثروط، التي نحكم من خلالها أو نقيس عليها سلوكيات الأفراد أو الودئ الجماعات، والأعمال وأنماط التفكير والإجراءات"(ثحاتة والنجار ، بـع (هـ).

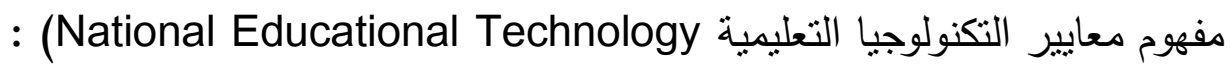
معايير تكنولوجيا التعليم للطلاب، وضعتها الجمعية الدولية للتكنولوجيا في التعليم 


\section{ILA الجمعية المصرية للقراءة والمعرفة عضو الجمعية الدولية للمعرفة}

لتحقيق الاستخدام (International Society for Technology in Education)

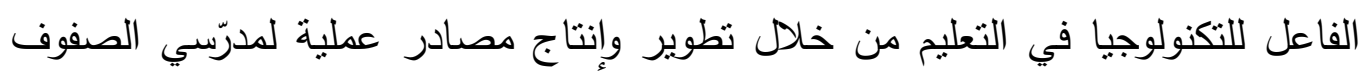

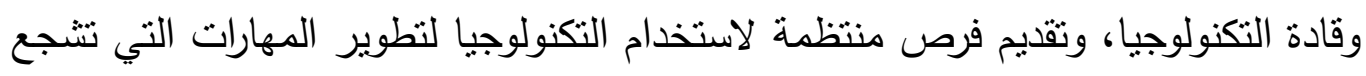

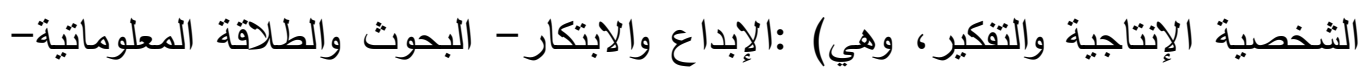

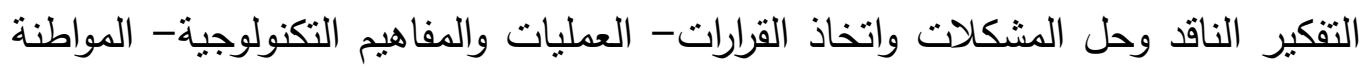

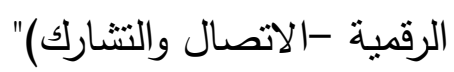

ISTE معايير

International Society for Technology in الجمعية الدولية للتكنولوجيا في التعليم

Education

لماذا نُطبق المعايير ؟

• للنوجه الصحيح نحو النوظيف الفعال للتنكولوجيا

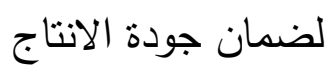

ل لضمان تحقق الفائدة

ضرورة التحول إلى المعايير الدولية

لاللوصول إلى التتافسية العالمية في مجال دمج التكتولوجيا في التعليم

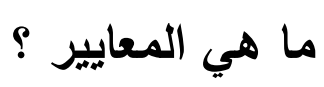

ISTE NETS-T معايير المعلمون

تختص هذه المعايير لتوجيه المعلمين بتوظيف التكنولوجيا في عمليات التعليم

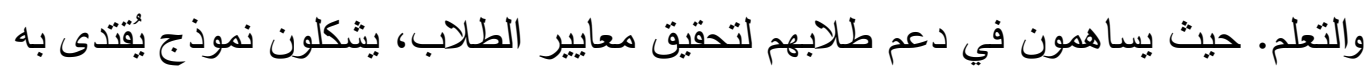

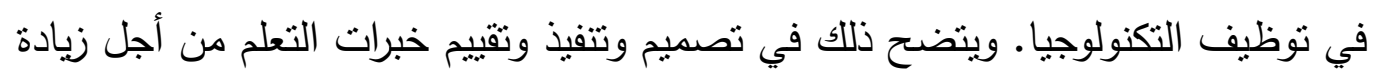

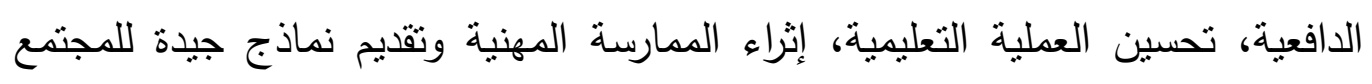

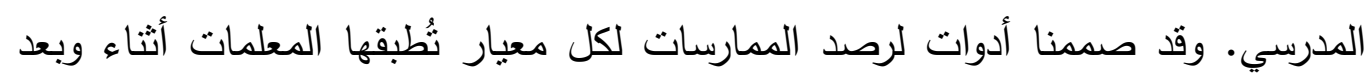
انتاجها وتوظيفها للتكنولوجيا 


\section{ILA الجمعية المصرية للقر اءة والمعرفة عضو الجمعية الدولية للمعرفة}

ISTE NETS-S معايير الطلاب

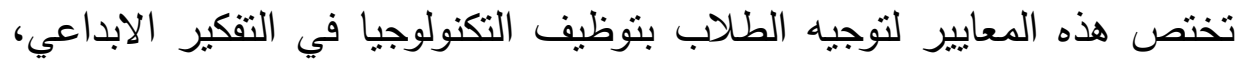
بناء المعرفة وتطوير الدنتجات والعطليات الابتكارية. وقد صممنا أدوات لرصد الممارسات لكل معيار مع تتفيذ وش عمل لدعم تطبيقها معايير الجمعية الدولية للتكنولوجيا في مجال التعليم ISTE للطلاب (مصطفى جودت ، $(r \cdot 17$ تصف معايير ISTE للطلاب المهارات المعرفية التي يحتاجونها لنقدمه ونموهم اللمساهمة في مجتمع عالمي مترابط ومتغير باستمرار

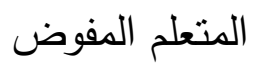

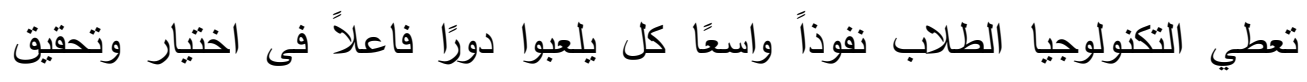

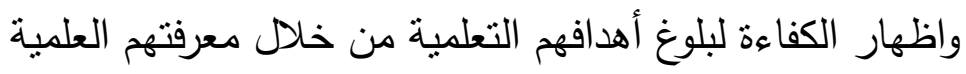

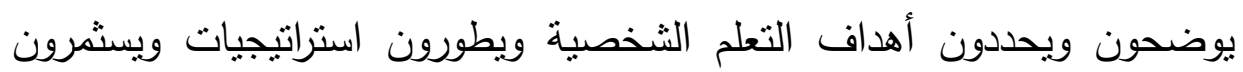
التكنولوجيا لإنجاز هذه الأهداف.

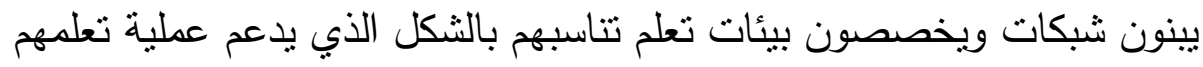
يستخدمون التكنولوجيا للحصول على التغذية الراجعة التي تطور ممارستهم ولإظهار ما تعلموه بطرائق مختلفة.

بستوعبون الدفاهيم الأساسية للعمليات التكنولوجية ويظهرون القدرة على اختيار واستعمال واستكثاف التكنولوجيات الحالية ويكونون قادرين على نقل معرفتهم للبحث فى التكنولوجيات المستحدثة الموفاطن الرقمي

يتعرف الطلاب حقوقهم وواجباتهم وفرص العيش والتعلم والعمل في عالم رقمي مترابط : يتصرفون بطرائق أمنة وقانونية وأخلاقية

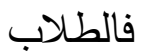




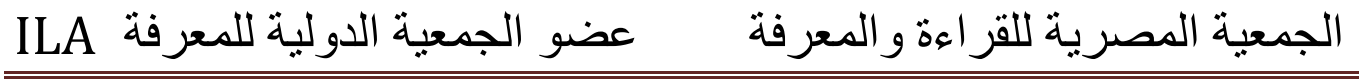

- - يبنون وبنمون هوية وسمعة رقمية ، ويكونون على وعي بديمومة ما يقومون به

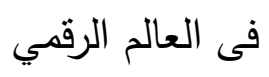

- ينخرطون في سلوك إيجابي ، أمن ، قانوني وأخلاقي عند استخدام التكنولوجيا

$$
\text { ومن ضمنها شبكات الإنترنت ومواقع التواصل الاجتماعي }
$$

- يظهرون فهماً شاملاً واحترامًا للحقوق والواجبات في استخدام ونشر الملكية

الفكربة

- يديرون بياناتهم الثخصية للحفاظ على الخصوصية الرقمية وهم يدركون بتقنية

جمع البيانات المستخدمة في تتبع أثار تصفحهم لشبكة الانترنت

$$
\text { منتج المعرفة }
$$

يجمع وينقد وينظم الطلاب مجموعة منتوعة من المصادر من خلال استعمال الأدوات الرقمية لبناء المعرفة ، وانشاء نتاج إبداعي والحصول على تجربة علمية ذات معنى لهم

$$
\text { ولغيرهم }
$$

فالطلاب

- - يخططون ويوظفون استراتيجيات بحث ناجحة لتحديد المعلومات والموارد الأخرى ،

$$
\text { لتحقيق نموهم الإبداعي والفكرى }
$$

- يقيمون صلاحية ودقة ومصداقية المعلومات والوسائط والبيانات والموارد الأخرى - - يستتبطون المعلومات من الموارد الرقمية من خلال استعمال أدوات وطرق متعددة

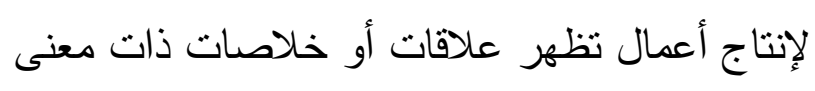

- يبنون المعرفة من خلا الاستكثاف الفاعل لمشاكل الحياة اليومية فى العالم

$$
\text { الواقعي وبطورون الأفكار والنظريات للوصول الى أجوبة وحلول }
$$

يستخدم الطلاب مجموعة من التقنيات المنتوعة في إطار عملية التصميم لتحديد

$$
\text { وحل المشاكل من خلال ابتكار وسائل جديدة ومفيدة }
$$




\section{ILA الجمعية المصرية للقر اءة والمعرفة عضو الجمعية الدولية للمعرفة}

فالطلاب

- يتخدمون عمليات تصميم منطورة لنوليد أفكار واختيار نظريات وخلق أعمال فنبة مبتكرة وحل مشاكل واقعية - يختارون ويستعملون وسائل رقمية لتخطيط ومعالجة عمليات التصميم التي تأخذ بعين الاعتبار العوائق والمخاطر المتوقعة - - يطورون ويختبرون ويصقلون نماذج كجزء من عملية التصميم الدورية - يظهرون القدرة على تخطي العثرات واستيعاب النتائج الغير منوقعة عند التعامل مع المشاكل التى ليس للايها حلول واضحة

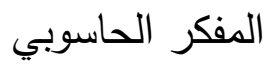

يطور الطلاب استراتيجيات ويستخدونها لفهم وحل المشاكل من خلال وسائل تظهر نفوذ وقوةالتكنولوجيا في تطوير واختبار الحلول فالطلاب - - يصيغون تعريف المشاكل على قياس الوسائل التى تعتمد على التكنولوجيا منل تحليل البيانات ، النماذج الدجردة والتفكي الحسابي فى استكثاف وايجاد الحلول - ـ يجمعون البيانات ويحددون البيانات ذات الصلة ويستخدمون الوسائل الرقمية لتحليلها ويعرضونها عبر وسائل متعددة لتسهيل حل المشاكل واتخاذ القرارات - يقسمون المشاكل إلى عدة أقسام ويستخرجون المعلومات الرئيسة ويطورون نماذج وصفية لفهم الأنظمة المعقدة أو تسهيل حل هذه المشاكل - - يفهون العمل المنهج المستقل ويستخدمون التفكير الحسابي لنطوير خطوات متلاحقة ولخلق واختبار حلول تلقائية

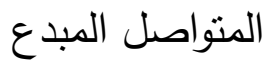




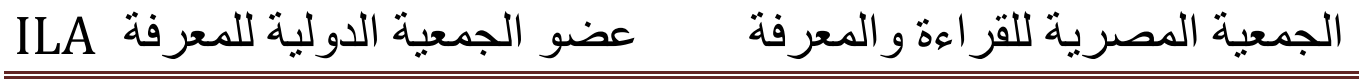

- يتواصل الطلاب بشكل واضح ويعبرون عن أنفسه بطريقة ابداعية لأغراض متعددة من خلال استخدام منصات وأدوات وأساليب وصيخ ووسائل إعلامية رقمية الفية لئل

$$
\text { متتاسبة مع أهدافهم }
$$

- يختارون المنصات والأدوات المناسبة لتحقيق أهدافهم الإبداعية والتواصلية

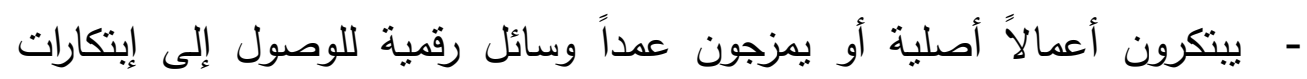
جديدة

- يوصلون الأفكار المعقدة بوضوح وفاعلية من خلال إنشاء واستعمال وسائل رقمية منتوعة منل الوسائل البصرية أو النماذج أة المحاكاة - ينشرون أو يعرضون المحتوى المناسب لإيصال الرسالة المرجوة إلى الفئة المستهدفة.

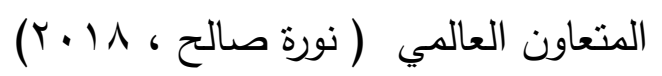

- - يستخدم الطلاب الوسائل الرقمية لتوسيع أفاقهم وإثراء تعلمهح من خلال التعاون

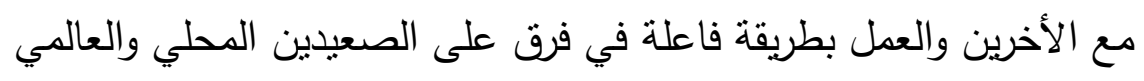
- - يستخدمون الأدوات الرقمية للتواصل مع متعلمين من خلفيات وثقافات منتوعة وينخرطون معهم في محاولة لتوسيع التفاهم وتبادل الخبرات بينهم - - يستخدمون التكنولوجيا للتعاون والعمل مع غيرهم كالأصدقاء والخبراء وأفراد المجتمع لفحص المسائل والثشاكل من خلال وجهات نظر متعددة

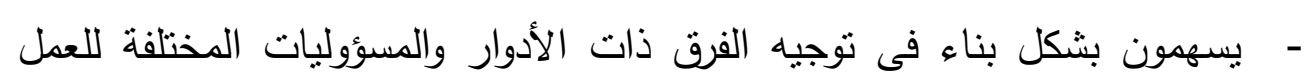
بشكل فاعل في سبيل تحقيق هدف موحد

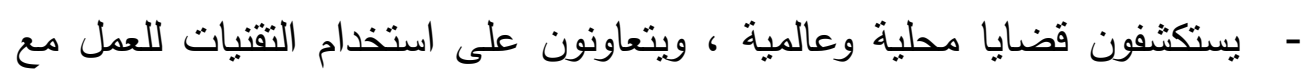
الأخربن ولاستقصاء الحلول. 


\section{الجمعية المصرية للقر اعة والمعرفة عضو الجمعية الدولية للمعرفة}

\section{ISTE NETS-C معايير المدربين على التكنولوجيا}

هذه المعايير موجها لمدربي التكنولوجيا وهي ما اتبعه فريق العمل في التنريب التباني وانتاج الوسائط التنرييية التي تضمنها تطبيق ( أدوات ) على الأجهزة الذكية وهي تُعنى بأهمية وضوح الروية لامج التكنولوجيا في التعليم والتعلم وتطبيقها لتعزيز التميز وإجراء التهاء تغيير جذري في البيئة التعليمية والتعلميه

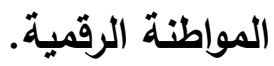

هي أحد المعايير وتم التركيز عليها من خلال رفع الوعي الثقافي والالتزام

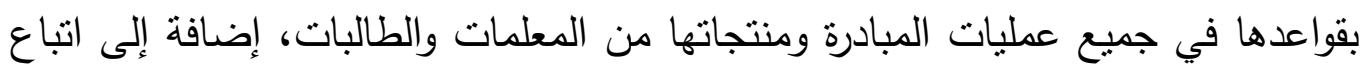

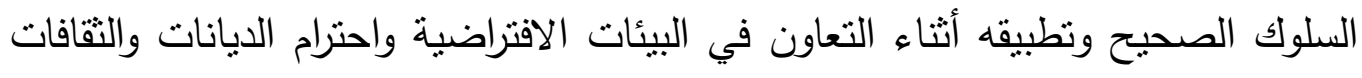

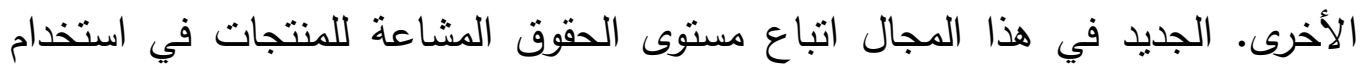
الصور والدقالات أو الوسائط من الثبكة العنكبوتية، حفظ الحقوق الفكرية للمبادرة والمنتجات ضمن نظام رخص المشاع الإبداعي لحقوق التأليف والنشر النش

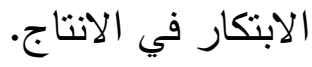

انتجنا تطبيق (أدوات) منوفر على الأجهزة الذكية التي تعمل بنظام التشغيل

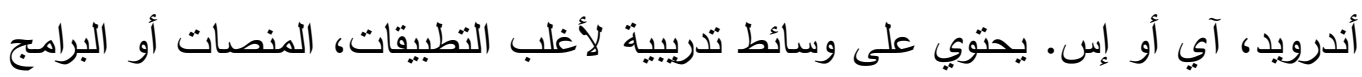

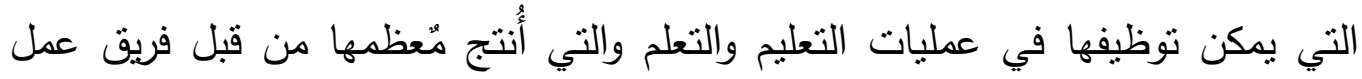
المبادرة .علاوة على دعم لتعلم ذوي الاحتياجات الخاصة ويُتري المحتوى العربي

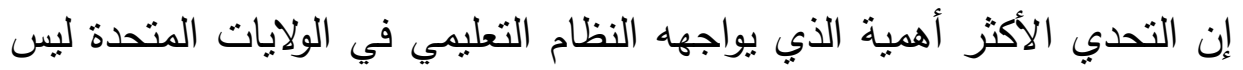

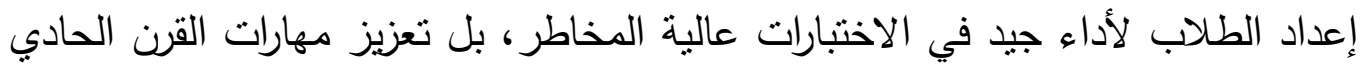

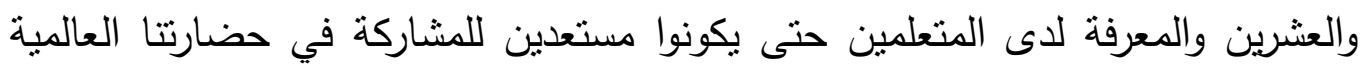

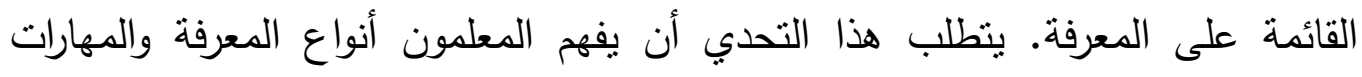

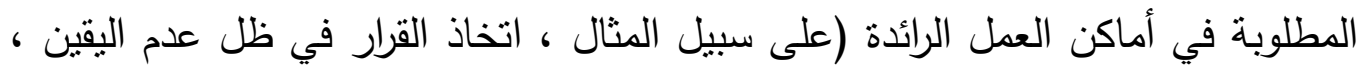

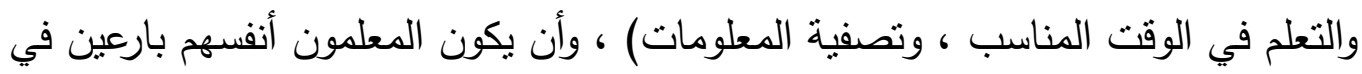




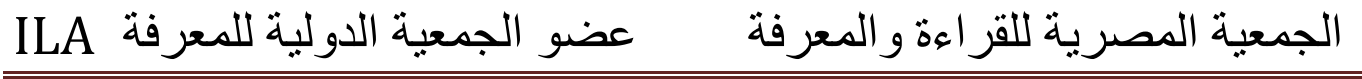

الإدرالك العام عالي المستوى ، المهارات العاطفية والاجتماعية مثل التفكير المنظومي والإبداع والتعاون.

حيث أصدرت الجمعية الدولية للتكنولوجيا في التعليم (ISTE) معاييرها الوطنية لتكنولوجيا التعليم للمعلمين (NETS-T) وتهدف إلى أن تكون هذه الوثيقة وثثقة مصاحبة لمعايير تكنولوجيا التعليم الوطنية للطلاب (NETS-S) التي تم إصدارها سابقًا. ـ تعكس هلئ هاتان المجموعتان من المعايير تحولًا جوهريًا في طريقة تفكير المعلمين بشأن التكنولوجيا في البيئة التعليمية. حتى إصدار هذه المعايير ، ركز مجال تكنولوجيا التعليم على "كيفية"

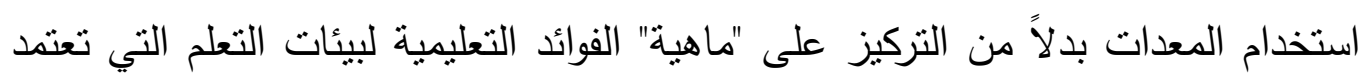
على التكنولوجيا (Maloy ، وآخرون ، (1) (ب). منت المعلمين الآخرين ذوي العقلية الإصلاحية ، يريد معلمو التكنولوجيا التركيز على التعلم بدلاً من اكتساب المهارات الآلية. وتشير حقيقة أن مبادرات ISTE التي تركز على المعلمين والطلاب إلى أنهخ

يتفقون مع تحذير كريس ديدي بأن المعلمين يجب أن "يفهموا أنواع المعرفة والمهارات المطلوبة في أماكن العمل المتطورة. وأن المعلمين أنفسهم بارعون في المهارات المعرفية والعاطفية والاجتماعية العامة ذات المستوى العالي منت التفكير المنظومي والإبداع والتعاون ". لذلك ، سيحتاج المعلمون إلى تبني التكنولوجيا إدراكيًا وفعالًا وإرادًا إذا كان لديهم أي أمل في المساعدة في إيصال طلابهم إلى القرن الحادي والعشرين الذي بتزايد فيه الطابع الرقمي.

ويكاد يكون من المتفق عليه أن النظرية السلوكية لم يعد لها تأثنير يذكر اليوم في مجال علم النفس التربوي، لكن من الواضح أن لها تطبيقات مؤثرة وفعالة في مجال يلال التعليم، منل الصياغة السلوكية للأهداف التعليمية، والتعليم المصغر ، وتحليل التفاعل لهل اللفظي، والكفايات التعليمية.

ويعتبر مصطلح الكفايات من المصطلحات الثائعة في مجالات متعددة بما فيها التربية، وفي التربية تتعدد أنواع ومجالات الكفايات فهناك الكفايات الفنية، و الكفايات 


\section{الجمعية المصرية للقر اءة والمعرفة عضو الجمعية الدولية للمعرفة}

التدريسية ، والكفايات الإدارية وغيرها، بالإضافة إلى أن الكفاية الرئيسية تتقسم إلى العديد

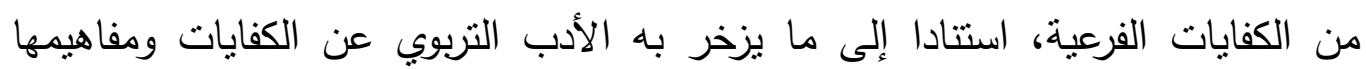
وأسس اشتقاقها، وما سنتطرق إليه في هذا المقال، هو مجالات استخدام الكفايات الترريسية تحديداً في العملية التعليمية، وسنتتاول هنا ثناث استخدامات وهي كما يلي: الكفايات وإعداد المعلم

لقد زاد الاهتمام ببرامج إعداد المعلمين القائمة على الكفايات، بحيث بدأ استخدامها على نطاق واسع في معظم البرامج المستخدمة في الدول المتقدمة، فمعرفة الكفايات تجعل من المككن رسم الخطوط العريضة لفلفة تربية المعلمين قبل الخدمة في كليات التربية وإعداد المعلمين." ويقوم مفهوم الكفايات التدريسية على مسلمة رئيسية مفادها أن عملية التدريس وعلى يمكن تحليلها إلى مجموعة من السلوكيات. ولقد تأثرت حركة إعداد المعلمين القائمة على على الكفايات بالمدرسة السلوكية، بالإضافة إلى ارتباطها عضويا بالبرنامج القائم على الأهداف إلى إعلى السلوكية الإجرائية. كما أن العوامل التي أدت إلى نشأة حركة تربية المعلمين القائمة على الكفايات

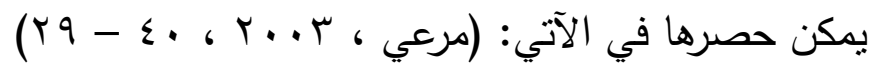

$$
\begin{aligned}
& \text { • اعتماد الكفاية بدل المعرفة. } \\
& \text { • ظهور حركة المسؤولية. } \\
& \text { • حركة منح الثهادات القائمة على الكفايات. } \\
& \text { • حركة التربية القائمة على العمل الميداني. } \\
& \text { • حركة تفريد التعليم. } \\
& \text { • التدريب المتجه نحو العمل. } \\
& \text { • تطور أساليب التقويم للمعلم. }
\end{aligned}
$$




\section{ILA الجمعية المصرية للقراءة والمعرفة عضو الجمعية الدولية للمعرفة}

Competency Based Teacher وبذلك فإن التربية بالكفايات Education CBTE Competency Based Teacher Certificate CBTC يُكمل الأخرى، فكلتاهما تؤكد على الأداء والتطبيق أكثر من المعرفة، وعلى أن معيار

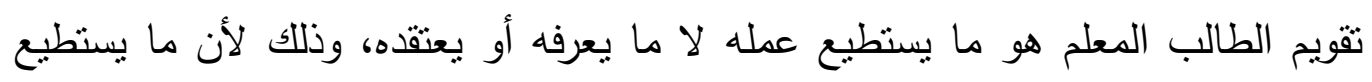
عمله يعكس ما يعرفه ويشعر به.

وتقوم فكرة إعداد المعلم القائم على الكفايات على عدة مبادئ منها :

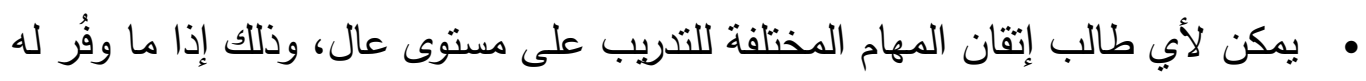

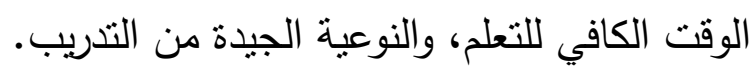

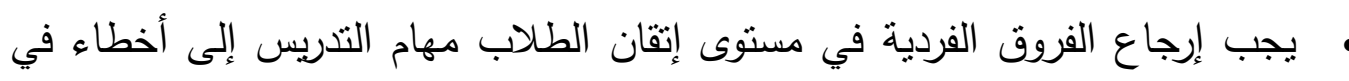
نظام التنريب، لا إلى خصائص المتعلمين.

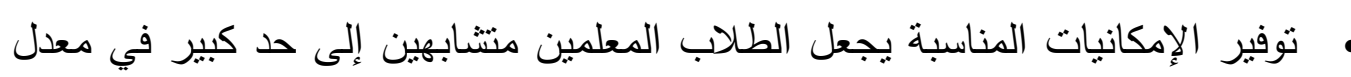

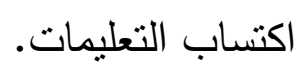
• يجب التركيز على الاختلافات في التعلم أكثر من التركيز على الاختلافات بين

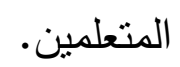
• إن أكثر العناصر أهمية في عملية التريس هي نوعية خبرات التعلم التي تتوفر

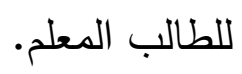
• ينتهي إعداد المعلم حين يثبت قدرته على أداء العمل التدريسي بغض النظر عن مدة التنريب.

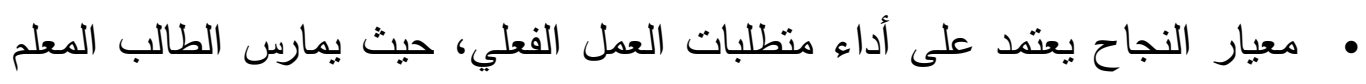

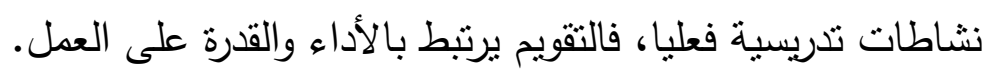




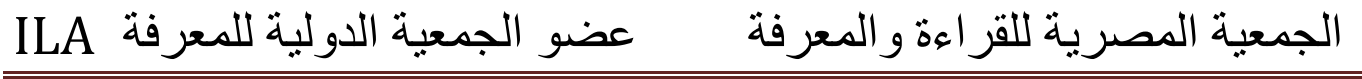

• تصميم برنامج الإعداد على أساس تقديم التدريب في ظروف واقعية مشابهة تماما للظروف التي سيعمل بها المتدربون بعد تخرجهم. • يتلقى المتدرب تغذية راجعة مستمرة تعطيه صورة دقيقة عن مدى التقدم اليومي.

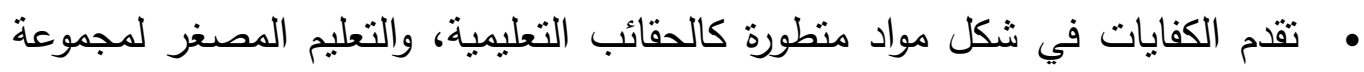
من النشاطات المرتبطة بكفاية معينة بحيث تؤدي إلى إتقان هذه الكفاية.(كمال زيتون

$$
\text { (or . r. . O }
$$

إن معرفة الكفايات يمكن أن تقوم بدور هام في سد فجوة عدم الانسجام أوالتباين الكبير بين خطط مؤسسات إعداد المعلمين الدراسية وبين ماهية الإعداد التربوي التخصصي المطلوب في تلاك البرامج بما يتفق والمهارات التدريسية المطلوبة فى معلم البيئة المكانية والزمانية المعينة. فالكفايات يمكن أن تشكل المعايير التي ترى الجهة المسؤولة عن توظيف المعلم أن على مؤسسات إعداده تتفيذ برامج مخرجاتها تتفق وما هو منصوص عليه في الكفايات المشتقة من الأطر المرجعية لها. الكفايات التدريسية وتمهين التعليم هذا الاستخدام يبدو واضحاً في التعريفات التي شملت الكفاية باعتبارها شرطا من الثروط المطلوبة للإجازة في مهنة التعليم، حيث نم تعريف الكفايات التدريسية : هي مجموعة المعارف والمهارات والإجراءات والاتجاهات التي يحتاجها المعلم للقيام بعمله بأقل

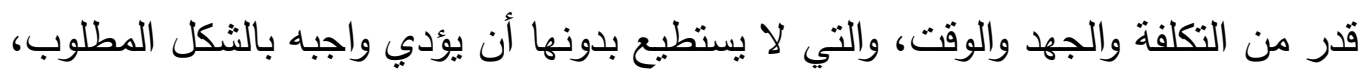

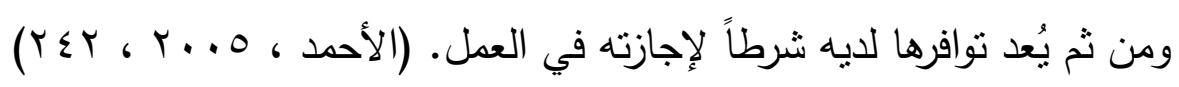

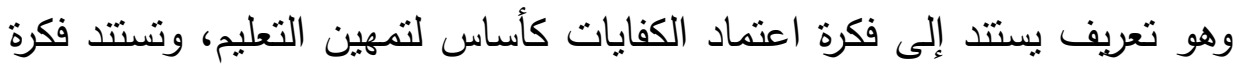

اختبارات المعلمين إلى أن التدريس مهنة لها متطلباتها وشروطها الخاصة منك المهن الأخرى كالطب والهندسة وغيرها، فالكفايات الأساسية للمعلمين يمكن اعتبارها معايير ومواصفات يفترض تحققها في المعلم. 


\section{ILA الجمعية المصرية للقراءة والمعرفة عضو الجمعية الدولية للمعرفة}

وتأتي الاستفادة من التجارب في المهن الأخرى - مثل مهنة الطب أو المحاسبة أو الهندسة على سبيل المثال، في ضرورة وضع الكفايات التي تشترطها وزارات التربية في من يلتحق بمهنة التعليم، وبالتالي تتم الملاعمة بين متطلبات الجهة الرئيسة لتوظيف المعلمين الجدد، وبين البرامج والخطط التي تعتمدها مؤسسات إعداد وتربية المعلم.

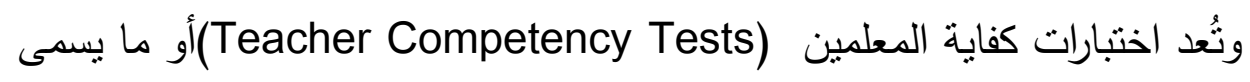
أحيانًا اختبارات المعلم في مقدمة المقاييس المستخدمة لمنح تراخيص مزاولة المهنة للمعلم، وأكثرها موضوعية لتقويم أداء المعلمين، ويمكن تلخيص مبررات اختبارات كفايات المعلمين

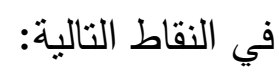
• دعم الاتجاه الداعي إلى أن التدريس مهنة لها متطلباتها وشروطها الخاصة بها مثل

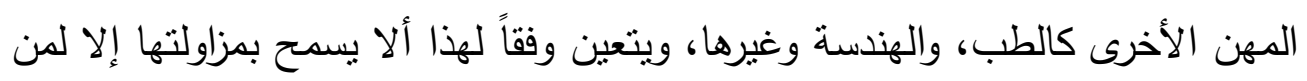
بتقنها. • يمكن الاستفادة من الاختبارات في تقويم المعلمين الذين يرغبون في الالتحاق لأول مرة بالمهنة للتعرف على إمكانات قبولهم. • تحديد جوانب النقص التي يمكن العمل على تحسينها فيما بعد بالتتسيق بين مؤسسات إنى إعداد المعلم وجهات توظيفه.

• انتقاء الأفضل من خلال تطبيق معايير دقيقة للاختبار عند توفر أعداد كبيرة من المتقدمين للانضمام إلى مهنة التدريس. الاستفادة منها في تقويم المعلمين أثناء الخدمة للحصول على تغذية راجعة تمكنهم من تحسين أدائهم.

وهناك الكثير من التجارب العربية والعالمية في مجال اختبارات المعلمين، ففي المملكة العربية السعودية قامت وزارة المعارف بتأسيس اختبارات المعلمين وفقاً لاعتبارات موضوعية وعلمية، وهذا أناح للوزارة فرصة انتقاء الأفضل من خلال تطبيق معايير دقيقة للاختبار الذي يتكون من الآتي: موطوع وعيه 


\section{الجمعية المصرية للقر اعة والمعرفة عضو الجمعية الدولية للمعرفة ILA}

\section{الكفايات التريوية التي تثمل}

- سياسة التعليم ونظمه في المملكة، مفهوم التربية والمناهج وطرق التدريس

$$
\text { وغيرها من فروع التخصصات التربوية. }
$$

- المهارات اللغوية (مهارة اللغة العربية قراءةً وكتابةً وفهمًا).

- المهارات العددية (الحد الأدنى من المهارات العددية التي تساعد المعلم

$$
\text { على أداء مهمته وخاصة المتعلقة بتقويم أداء الطالب). }
$$

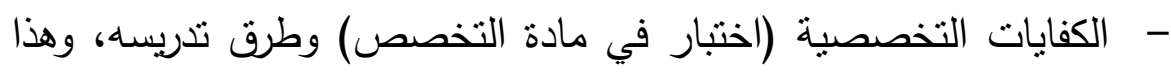

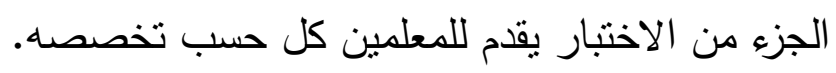

وفي اليابان، ينقام المعلم لاختبار من أجل التعيين بعد اجتيازه مرحلتي الدراسة الجامعية والتدريب العملي بنجاح وينكون الاختبار العام من: • • اختبار في المادة أو المواد التي سيقوم بنتريسها.

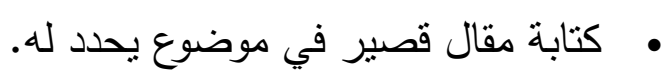
• اختبار شخصي في شكل مقابلة.

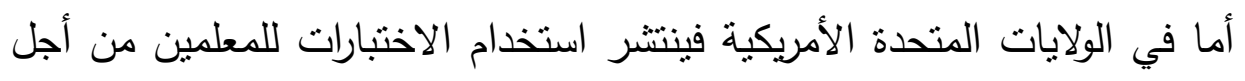

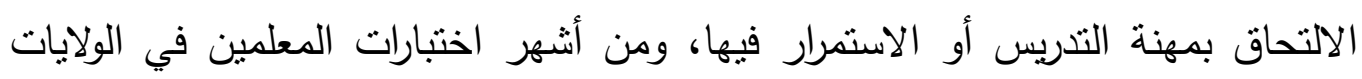

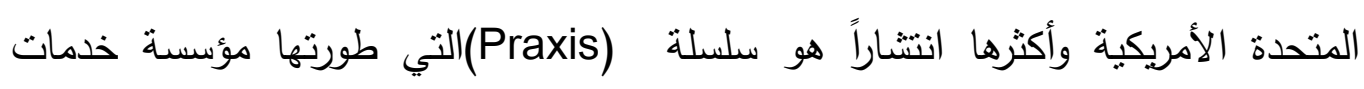
الاختبارات Educational Testing Services، حيث تطبق في معظم الولايات بهدف منح رخصة التدريس وتجديدها. وتتضمن هذه الاختبارات:

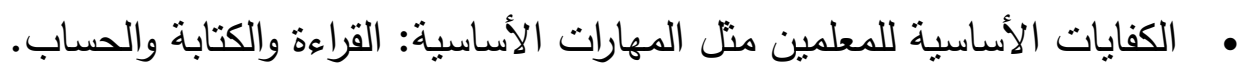
• ادة التخصص وطرق تدريسها.

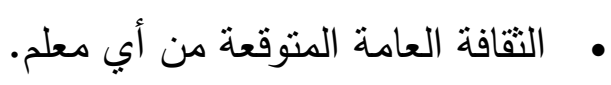




\section{الجمعية المصرية للقر اءة و المعرفة عضو الجمعية الدولية للمعرفة}

\section{الكفايات وتقويم أداء المعلم}

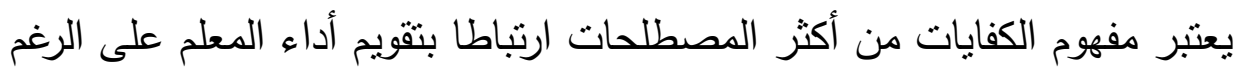

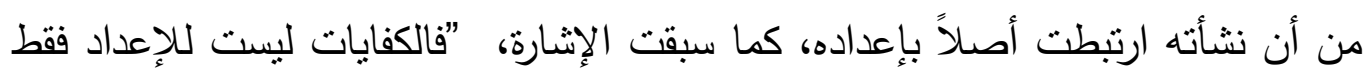

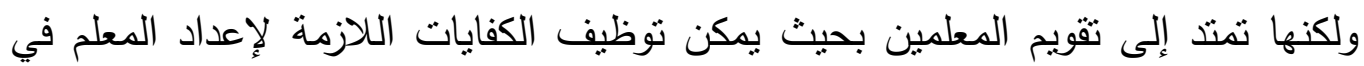

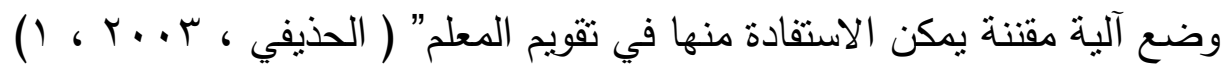

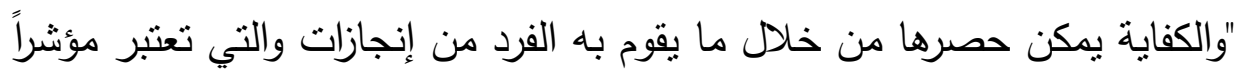

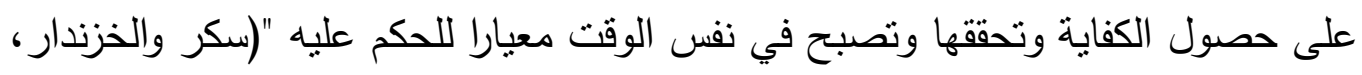
(Irr \& r... ومن المبررات التي يمكن أن تدعم استخدام الكفايات في تقويم أداء المعلم التدريسي تتمثل نذكر: • دعم الملاحظات الصفية التي يقوم بها الإشراف التربوي لتقويم أداء المعلم بمعايير موضوعية تعتمد على اختبارات كفايات المعلمين المقننة.

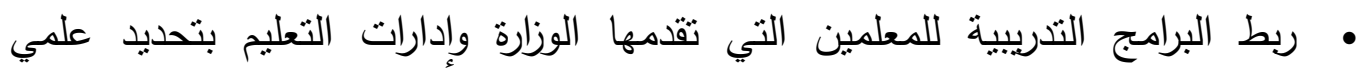
لاحتياجاتهم التندريبية. • كونها معايير للممارسة الترريسية الجيدة والتي يسنطيع المعلم بالرجوع إليها، تقويم

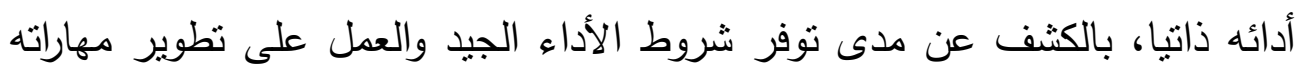
فيعزز الجوانب الإيجابية ويعدل الجوانب السلبية.

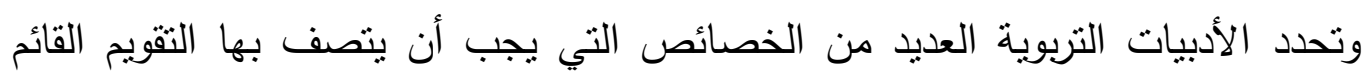

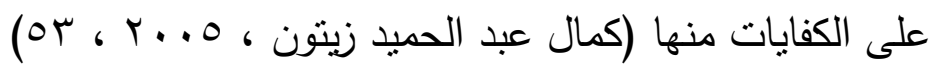

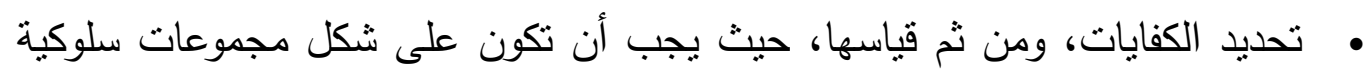
لأن سلوكيات التدريس داخل الصف لا تظهر كمفردات سلوكية مفككة، بل كمجموعة من السلوكيات المتتابعة والمترابطة بعلاقة ما.

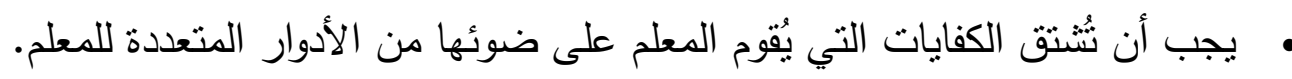




\section{ILA الجمعية المصرية للقر اءة والمعرفة عضو الجمعية الدولية للمعرفة}

• يجب ن يكون المعلم على علم بالكفايات التي سيُوَّم على أساسها وعلى الكيفية الإجرائية لاستخدامها في تقويمه.

تتائج الدراسة وتفسيرها

بعد الانتهاء من إجراء المقابلة والملاحظة الميدانية ، قام الباحث بتفريغ البيانات وتحليلها على النحو التالي : ع أن أولاً : نتائج الملاحظة أظهرت نتائج الملاحظة التى شملت عدد (ع) معلمين أحياء بالمرحلةالثانوية بالمملكة العربية السعودية بواقع (ع) حصص لكل معلم ، الأتى :

\begin{tabular}{|c|c|}
\hline الكفايات المستخدامة & عدد المعلمين \\
\hline تشجيع الطلاب ت يقوم المعلم بالثناء على جميع اجابات الطلاب ويستخدم التعزيز الرقمي & $\varepsilon$ \\
\hline يوظف المعلم أساليب تعليمية متتوعة لجميع ماريع أنماط الطلاب الطلاب & 1 \\
\hline تقديم انموذج للعمل والتعليم في العصر الرقمي المعلم أدوات تقنية متعددة تدعم نجاح الطلاب وابداعهم & 1 \\
\hline 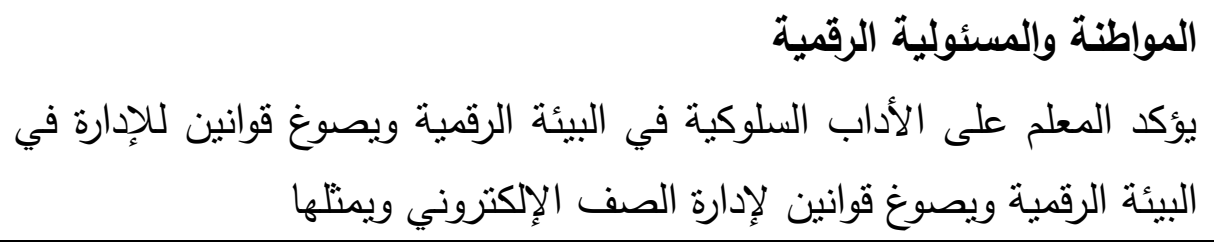 & $\varepsilon$ \\
\hline 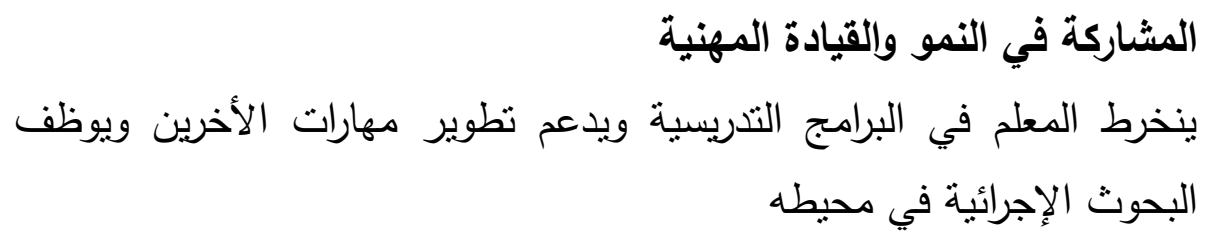 & r \\
\hline
\end{tabular}




\section{ILA الجمعية المصرية للقر اءة والمعرفة عضو الجمعية الدولية للمعرفة}

ثانيًا : نتائج المقابلة الثخصية لمعلمي العلوم : نركزت نتائج المقابلة على الإبل

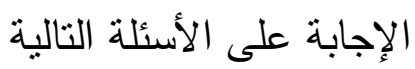

\begin{tabular}{|c|c|}
\hline | الكفايات المستخدمة & عدد المعلمين \\
\hline ل لدى الإلمام بماهية التعليم الإلكتروني & 1 \\
\hline لدي الإلمام بخصائص التعليم الإككتروني & r \\
\hline ل لدي الإلمام بأنماط التعليم الإلكتروني & $\varepsilon$ \\
\hline ل لدي الإلمام بفوائد التعليم الإلكتروني & $\varepsilon$ \\
\hline |لدي الإلمام بأهداف التعليم الإلكتروني & $\varepsilon$ \\
\hline |لدي الإلمام بإيجابيات التعليم الإلكتروني & $\varepsilon$ \\
\hline لإي الإلمام بسلبيات التعليم الإككتروني & r \\
\hline لدي الإلمام بمهام معلم الأحياء فى التعليم الإلكتروني & $\varepsilon$ \\
\hline |لدي الإلمام بخطوات التحول إلى التعليم الإلكتروني & r \\
\hline لدي الإلمام بمواصفات الأجهزة والبرامج في التعليم الإككتروني & r \\
\hline للدي الإلمام بالصعوبات التي تواجه تطبيق واستخدام التعليم الإككتروني & r \\
\hline
\end{tabular}

الاستنتاجات

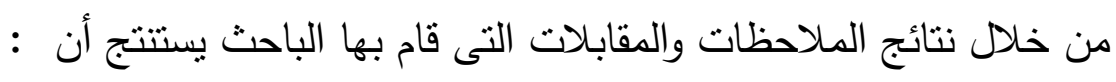
1. أهمية إلمام المعلمين بفوائد التعليم الإلكتروني

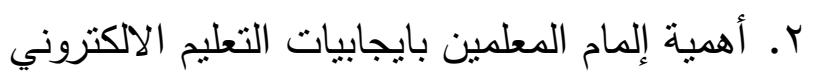

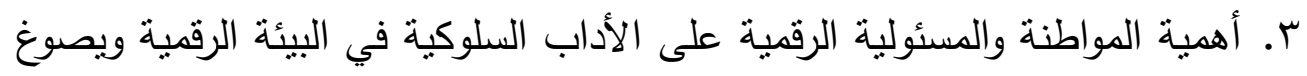

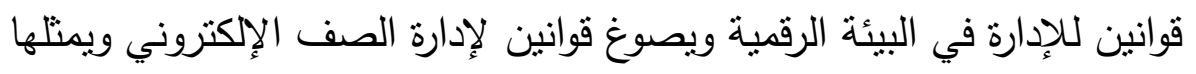

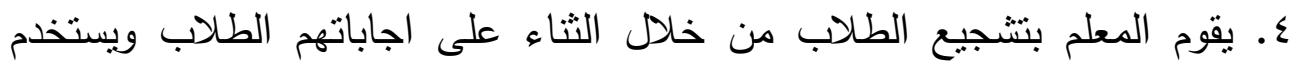

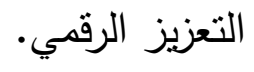




\section{ILA الجمعية المصرية للقر اءة والمعرفة عضو الجمعية الدولية للمعرفة}

\section{توصيات البحث}

في ضوء نتائج البحث الحالى يوصي الباحث بالآتي :-

1. ضرورة الاهتمام بالمعايير العالمية لتكنولوجيا التعليم (ISTM) من قبل القائمين

على العملية التعليمية

r. ضرورة العمل على إكساب المعلمين والطلاب المعايير العالمية لتكنولوجيا التعليم

لما لها من أهمية كبيرة فى التطور العلمي فى العصر الحالى لكئل

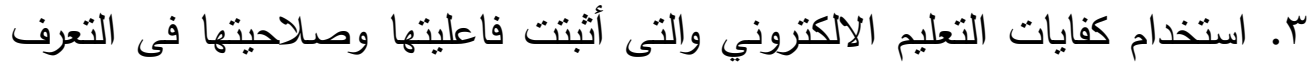
على كفايات التعلم الأكتروني لدى معلمى الأحياء بالمرخلة الثانوية وكنلك طلاب

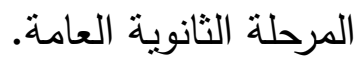

ع. أن تقوم الجهات المعنية ووزارة التربية والتعليم بزيادة الاهتمام بالبنية التكنولوجية

الازمة بجميع الدارس على مستوى المكلة العربية السعودية

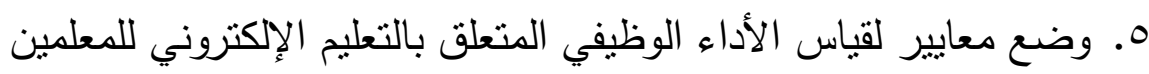

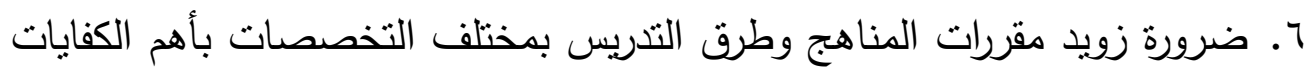

الإككترونية والمهارات التى يجب أن يتقنها المعلم ، وذللك لمواكبة العصر الرقدي بلهي

$$
\text { الحديث: }
$$

النتائج الخاصة بالتطبيق على الطلاب - عدد العنية 10 طالب وطالبة

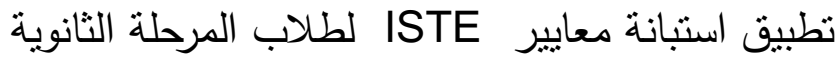

\begin{tabular}{|c|c|c|c|}
\hline بدرجة & متوسطة & كبرجة - كبيرة & 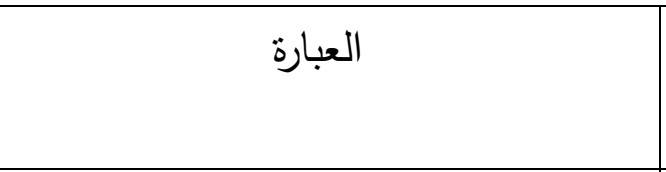 \\
\hline- & - & 10 & أستطيع فتح جهاز الكمبيوتر وإغلاقه جيداً \\
\hline 0 & 0 & 0 & 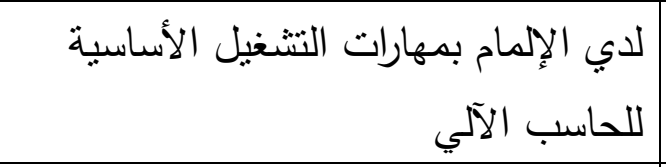 \\
\hline r & $r$ & 1. & File استطيع إنشاء ملف \\
\hline
\end{tabular}




\section{الجمعية المصرية للقر اعة و المعرفة عضو الجمعية الدولية للمعرفة ILA}

\begin{tabular}{|c|c|c|c|c|}
\hline r & r & 11 & استطيع حفظ الملف & $\varepsilon$ \\
\hline 1 & r & ir & استطيع نسخ الملف & 0 \\
\hline 1 & r & س & أستطيع تعديل الملف & 7 \\
\hline 0 & 0 & 0 & استطيع توصيل الطابعة & V \\
\hline r & 0 & $\Lambda$ & Word استطيع استخدم برنامج & $\Lambda$ \\
\hline r & $\varepsilon$ & $\Lambda$ & PowerPoint استطيع استخدم برنامج & 9 \\
\hline 0 & 0 & 0 & الانترنتع التعامل مع التبكة العنكبوتية & - \\
\hline
\end{tabular}

تطبيق بطاقة المقابلة المفتوحة لتحديد التصور تتمية كفايات التعليم الإلكتروني في ضوء معابير ISTE لدى معلمي وطلاب المرحلة الثانوبة.

\begin{tabular}{|c|c|c|c|c|c|}
\hline بدربة & مثورجة & كبرجة بيزة & الكفايات الفرعية & الكفايات أريسبة & م \\
\hline 1 & $r$ & $1 \%$ & 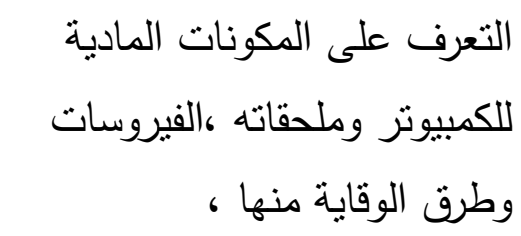 & $\begin{array}{l}\text { الكفايات العامة } \\
\text { (1) كفايات }\end{array}$ & .1 \\
\hline r & $Y$ & 1. & التعرف على برمجيات التشغيل & متعلقة بالثثقافة & \\
\hline r & $Y$ & 1. & للكمبيوتز في العملية التعليمية المختلفة & & \\
\hline - & - & 0 & التعرف على المصطلحات & & \\
\hline- & 1 & $1 \varepsilon$ & استخدام لوحة المفاتيح والفأرة & (Y) كفايات (Y) & \\
\hline- & 0 & 1. & كيفية التعامل مع وحدات الإدخال & متعلقة بمهارات & \\
\hline
\end{tabular}




\section{الجمعية المصرية للقر اعة و المعرفة عضو الجمعية الدولية للمعرفة ILA}

\begin{tabular}{|c|c|c|c|c|}
\hline & & & والإخراج & استخدام \\
\hline 1 & r & $1 Y$ & كيفية التعامل مع سطح المكتب & الكمبيوتر \\
\hline 0 & 0 & 0 & التختي توام مجموعة برامج الأوفيس، على المشكلات الفنية & \\
\hline 0 & - & 0 & التعامل مع وحدات التخزين & \\
\hline 0 & 0 & 0 & 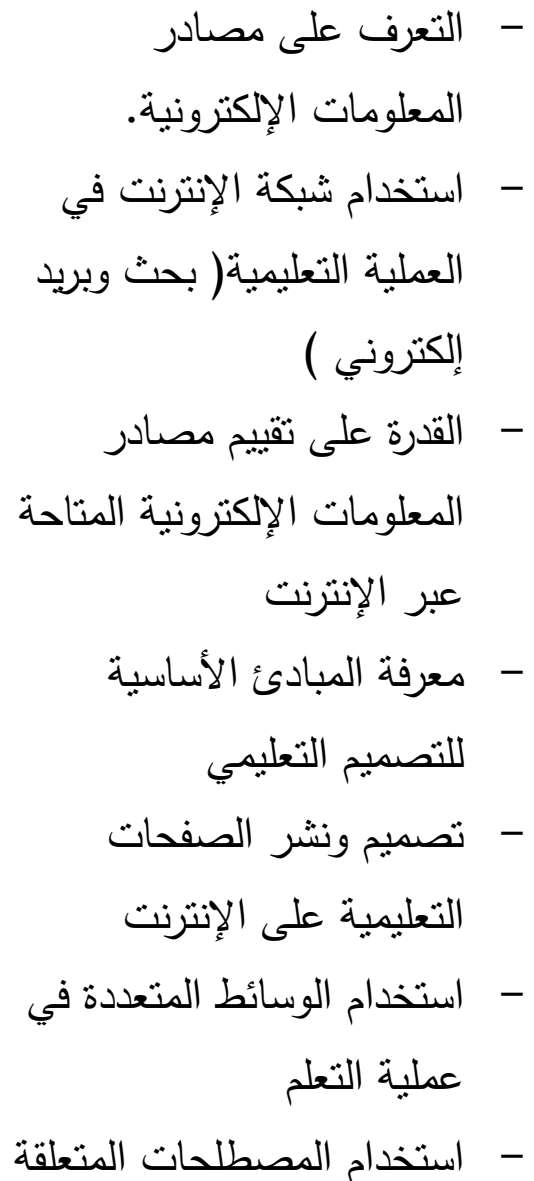 & متعلقة بالثثافة كفاباتة \\
\hline
\end{tabular}




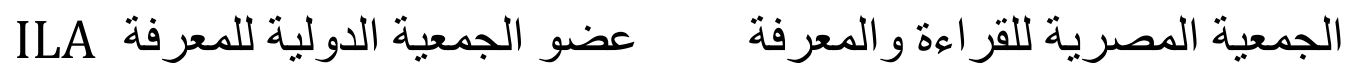

\begin{tabular}{|c|c|c|c|c|c|}
\hline & & & بتكنولوجيا المعلومات. & & \\
\hline 0 & 0 & 0 & 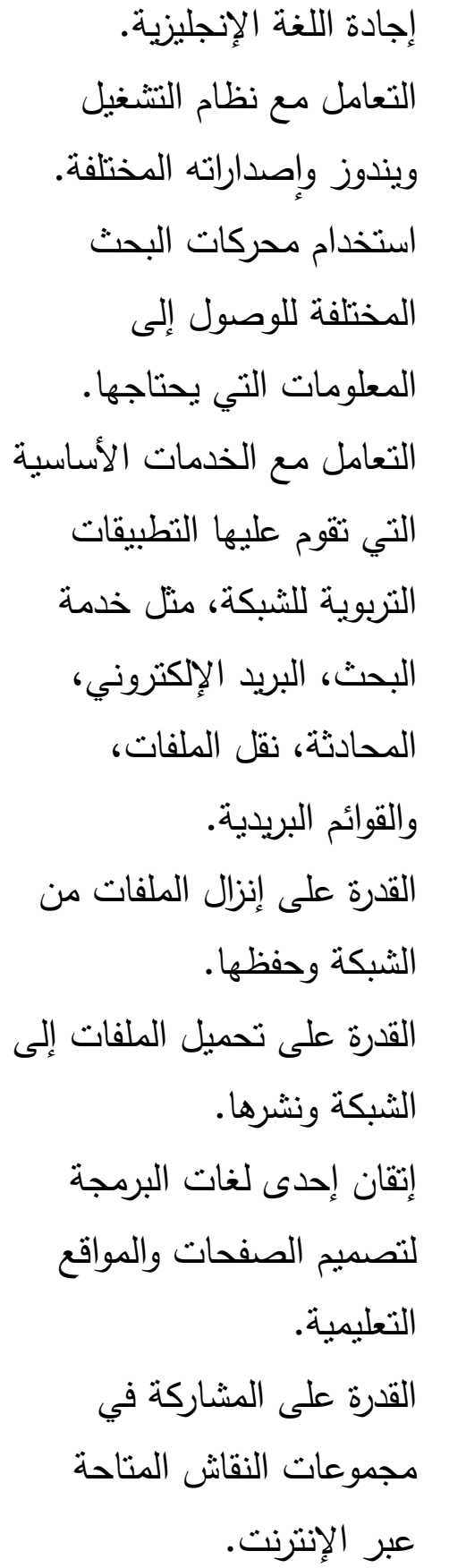 & ثانياً: كفايات &.$r$ \\
\hline
\end{tabular}




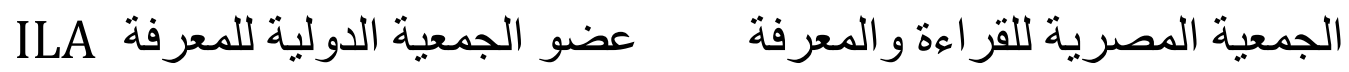

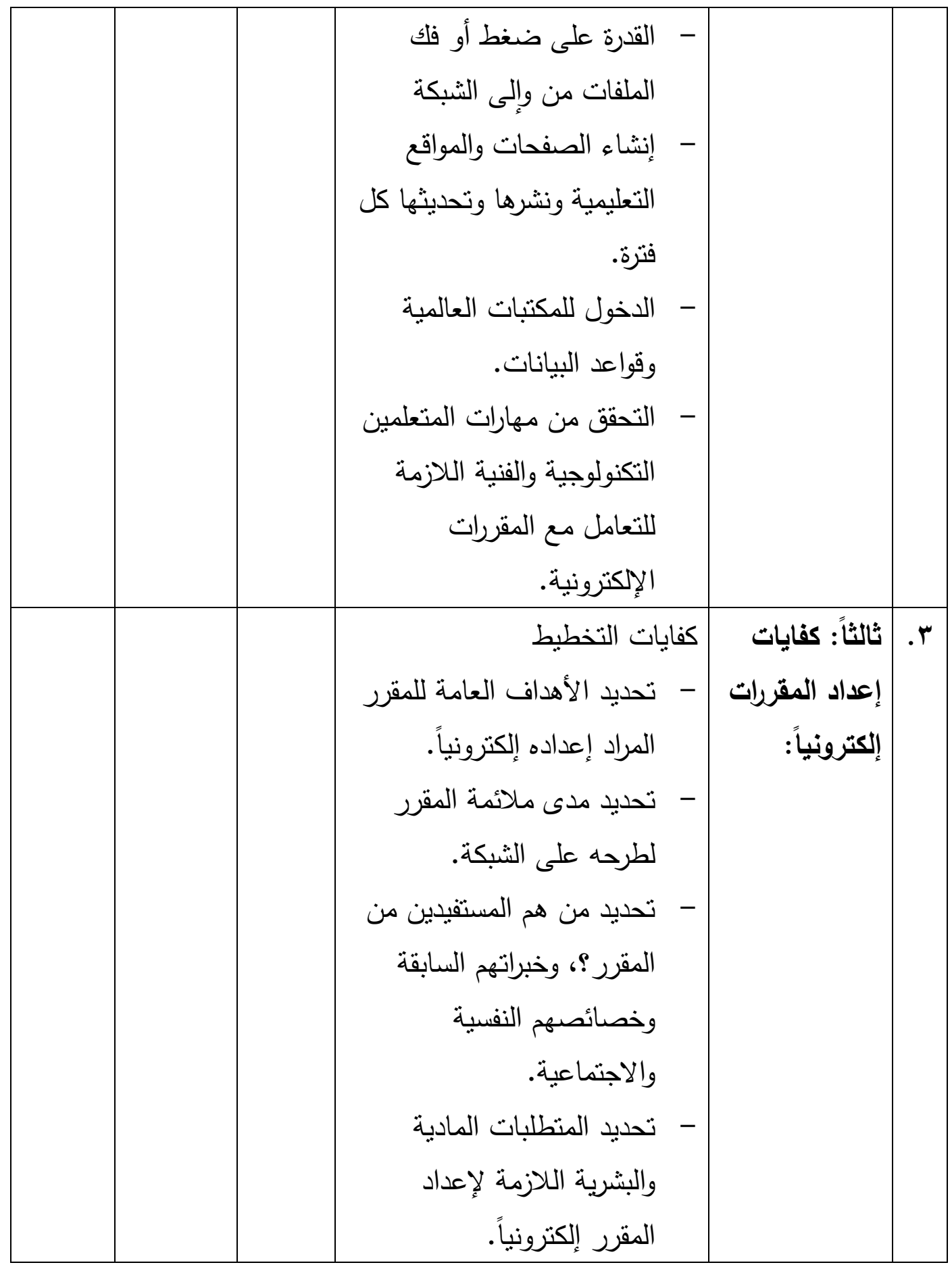




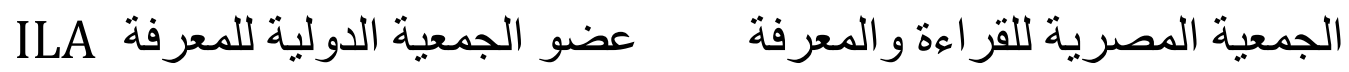

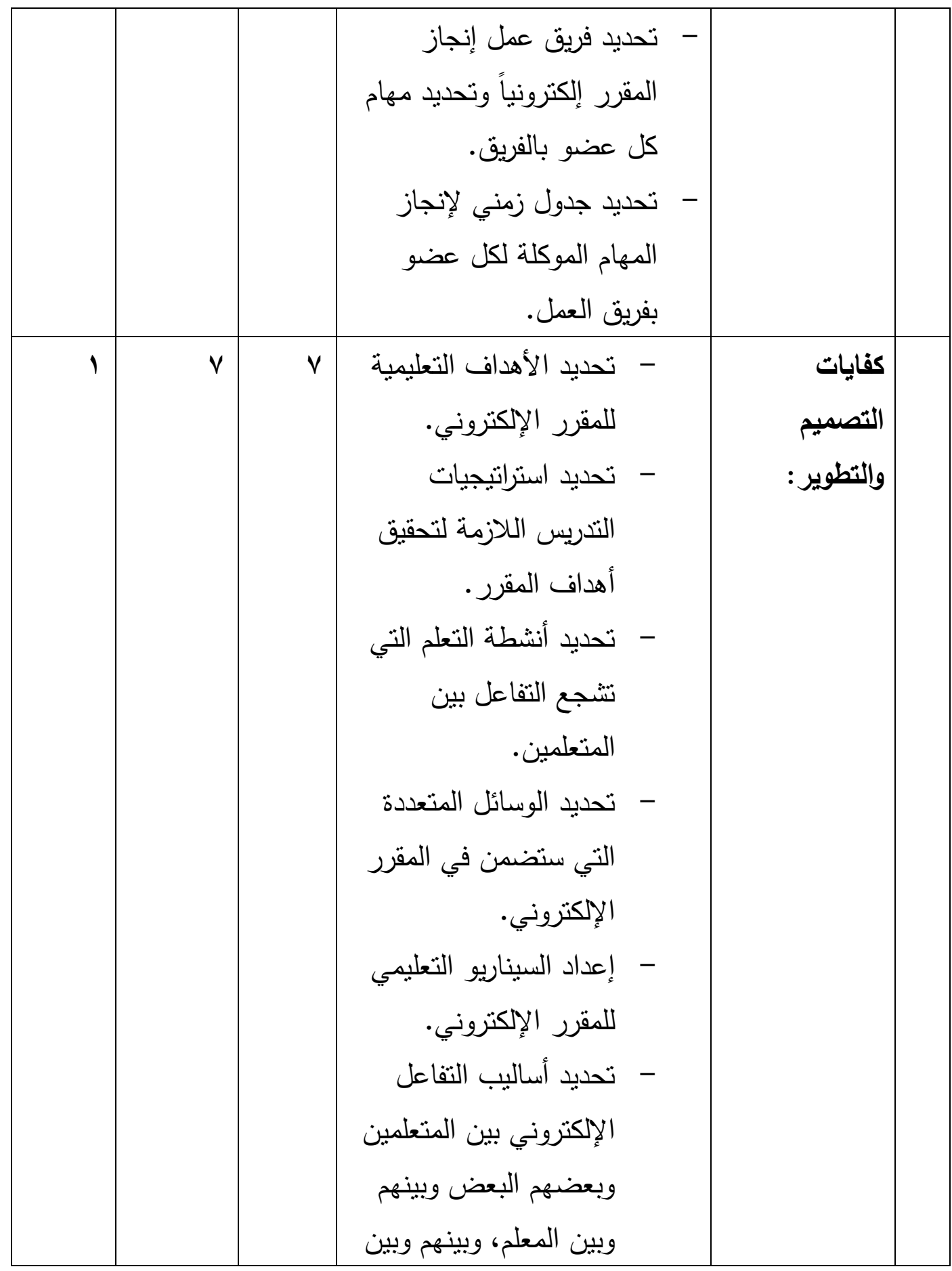




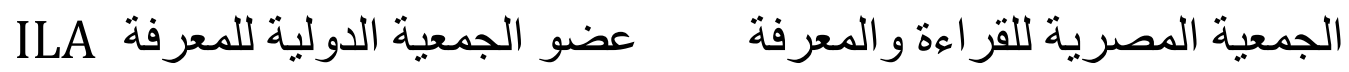

\begin{tabular}{|c|c|c|c|c|}
\hline & & & 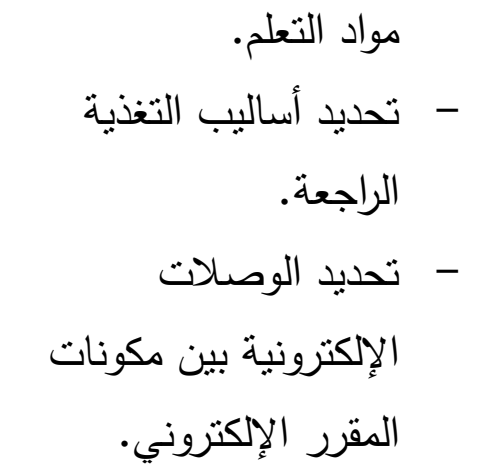 & \\
\hline$\varepsilon$ & 7 & 0 & 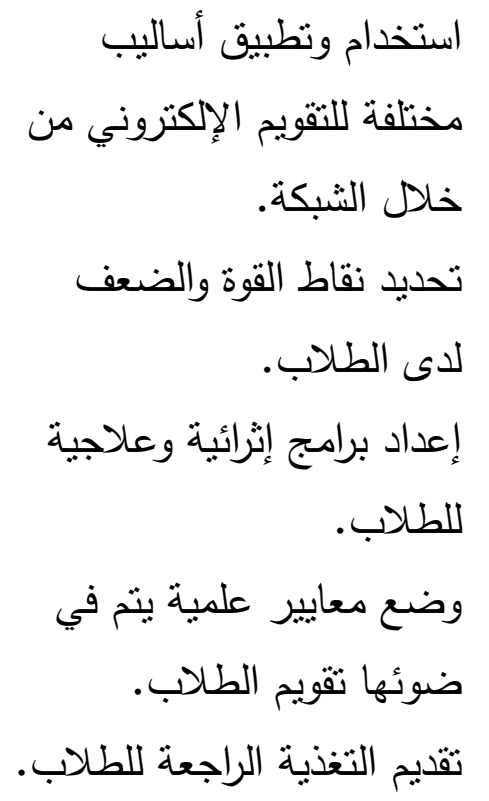 & كفايات التقويم \\
\hline 0 & $\varepsilon$ & 7 & القدرة على تتظيم الوقت لتقديم & كفايات إدارة \\
\hline
\end{tabular}




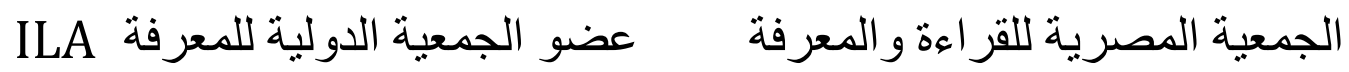

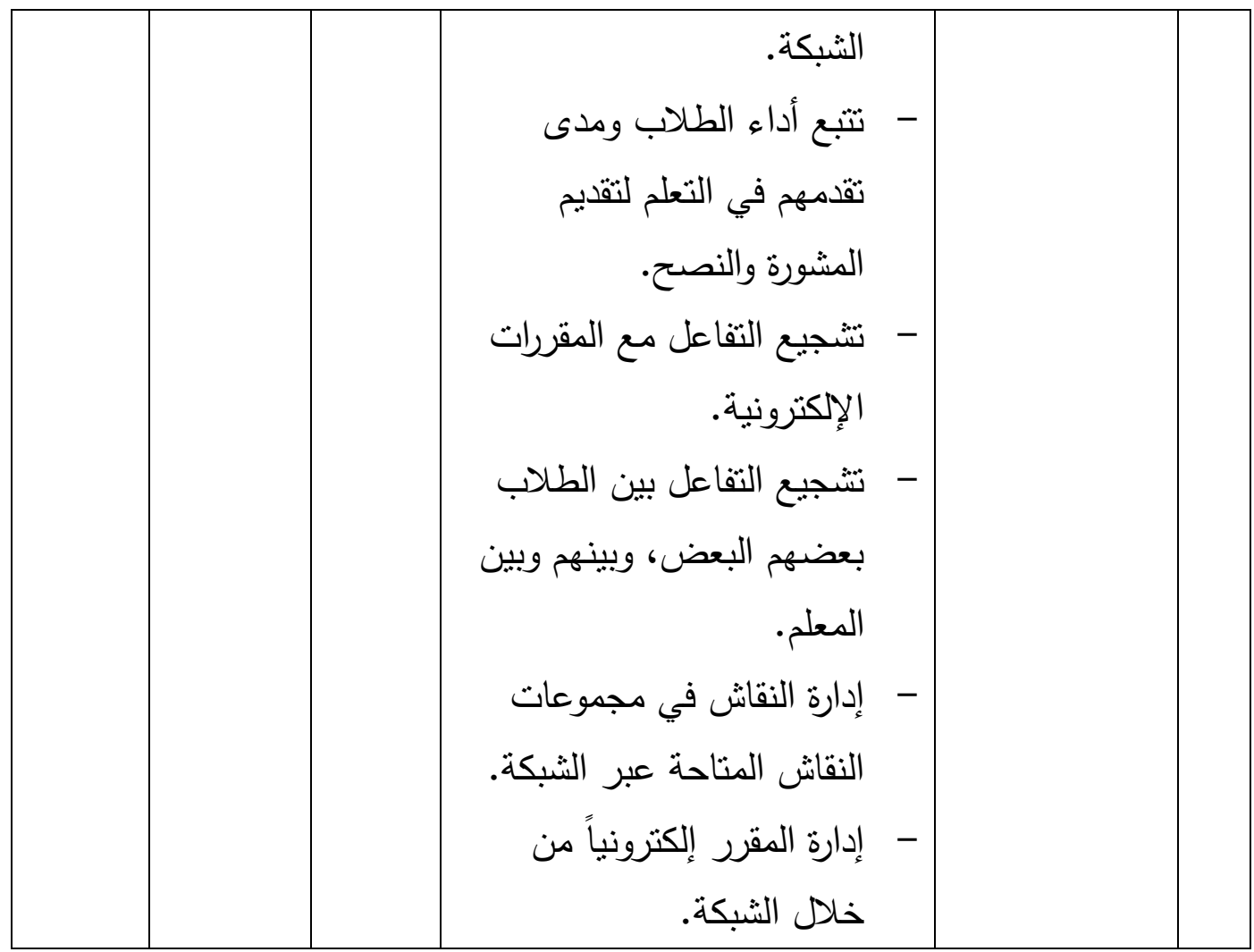

تطبيق أدوات البحث وتحليل النتائج تحليل المقابلة الشخصية - بطاقة الملاحظة لمعلمي العلوم بالمرحلة الثانوية لبناء ISTE تصور لتنمية كفايات التعليم الإلكتروني في ضوء معايير

أولاً : البيانات الأولية

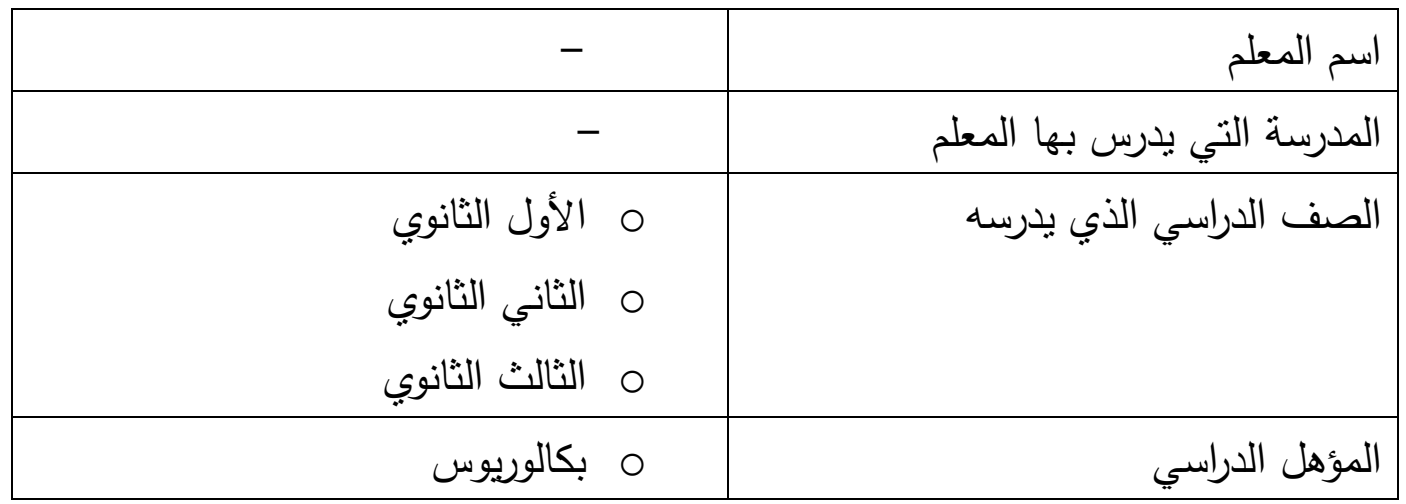




\section{ILA الجمعية المصرية للقر اءة والمعرفة عضو الجمعية الدولية للمعرفة}

\begin{tabular}{|c|c|c|}
\hline دكالوربوس مع إعداد تزبوي & $\begin{array}{l}0 \\
0\end{array}$ & \\
\hline 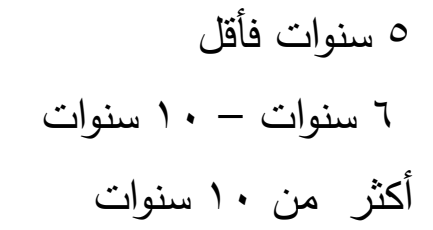 & $\begin{array}{l}0 \\
0 \\
0\end{array}$ & سنوات الخدمة \\
\hline 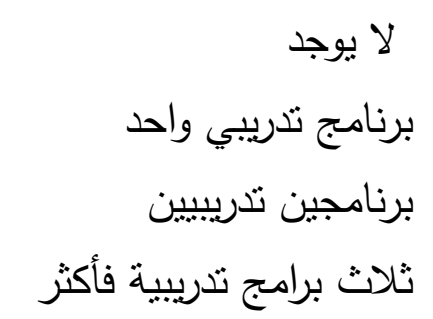 & $\begin{array}{l}0 \\
0 \\
0 \\
0\end{array}$ & الالبرامج التدربيبة في مجال التعليم \\
\hline & & تاربخ اجراء الملاحظة \\
\hline الألأحد الأثتين & $\begin{array}{l}0 \\
0 \\
0 \\
0 \\
0\end{array}$ & اليوم الذي تمت فيه الملاحظة \\
\hline & & توقيت إجراء الملاحظة \\
\hline
\end{tabular}

ثانيًا: المحاور الرئيسية للمقابلة الثخصية ويطاقة الملاحظة لمعلمي العلوم بالمرحلة

\begin{tabular}{|c|c|c|c|}
\hline بطاقة & المقابلة & المحار الرئيسة & r \\
\hline الملاحظة & الثخصية & & \\
\hline أدوات & أدوات & & \\
\hline جمع & جمع & & \\
\hline
\end{tabular}




\section{الجمعية المصرية للقر اعة و المعرفة عضو الجمعية الدولية للمعرفة ILA}

\begin{tabular}{|c|c|c|c|c|c|}
\hline \multicolumn{2}{|c|}{ البيانات } & \multicolumn{2}{|c|}{ البيانات } & & \\
\hline ق & ق & $\begin{array}{l}r \\
r\end{array}$ & 15 & & \\
\hline$\sqrt{ }$ & $\sqrt{ }$ & $\sqrt{ }$ & $\sqrt{ }$ & تشتيع الطلاب & .1 \\
\hline$\sqrt{ }$ & & $\sqrt{ }$ & & تصمم وتطوير ممارسات تعلم وتعليم الطلاب المعلم أساليب تعليمية متتوعة لجميع أنماط الطلاب &.$r$ \\
\hline$\sqrt{ }$ & & & & 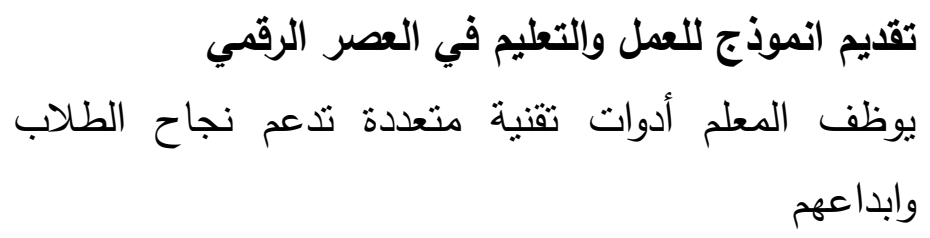 & r \\
\hline & & & $\sqrt{ }$ & 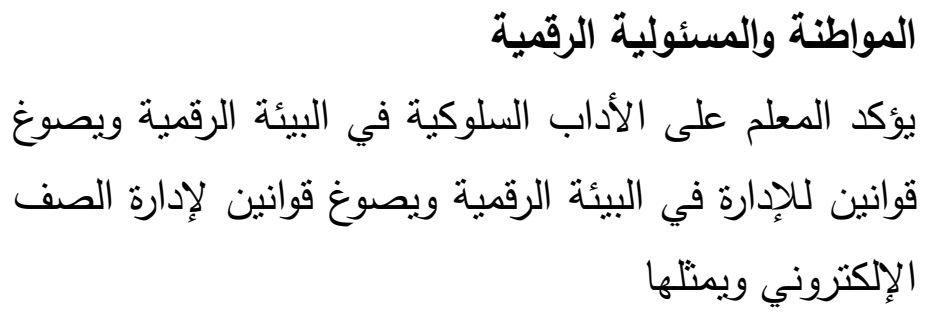 &.$\varepsilon$ \\
\hline$\sqrt{ }$ & $\sqrt{ }$ & $\sqrt{ }$ & $\sqrt{ }$ & 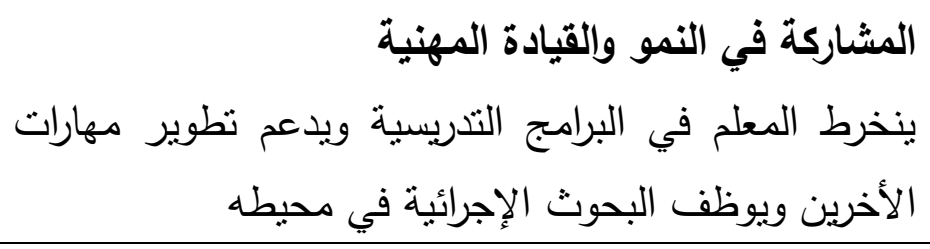 & .0 \\
\hline
\end{tabular}

\section{نتائج التطبيق}

ا ـ يستخدم المعلم أساليب التواصل الفعال داخل الفصل الدراسي خلال عرض الدرس ويقوم بتشجيع الطلاب والثناء الايجابي على اجابات الطلاب. 


\section{الجمعية المصرية للقر اعة والمعرفة عضو الجمعية الدولية للمعرفة}

r. يسعى المعلم إلى التأكيد على أهمية ودور السلوك والقيم الإيجابية والأخلاقية من خلال التعامل مع بيئات التعلم الرقمي وإدارة الصف الإكتروني. r. ينمي المعلم الثخصية القيادية والثجاعة الأدبية لدى الطلاب وبيحاول القضاء على الانطوائية التى يعانى منها عدد من الطلاب ، حيث أن التواصل الالكتروني

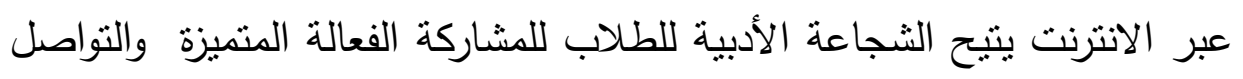
الفعال مع المعلم ومع الطلاب. ع. يطلب المعلمين من الطلاب إعداد بحوث وواجباتهم المنزلية من خلال الاطلاع على مواقع الإنترنت ومنصات التواصل والمكتبات الرقمية عبر الإنترنت ، ويتم Email تسليم أعمال الطلاب من خلا البر البربد الإكتروني ه. هناك بعض المواد التى لا يمكن الإكثفاء بالوسائط المطبوعة فقط فى تعلمها منل الموسيقى والفن وإجراء التجارب والعروض التوضيحية في العلوم حيث لا يمكن تدريسها بطريقة فعالة تقي بالمطلوب دون استخدام الوسائط المسموعة والمرئية الحديثة التي يوفرها التعليم الإكتروني.

7 . توصيل المناهج الدراسية وما تحتويه من معلومات بشكل سريع و دقيق للطلاب

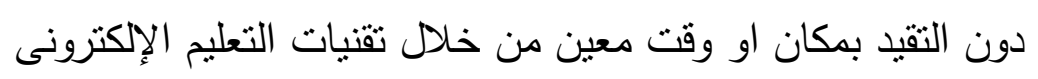
ملاحظات خلال المقابلة والملاحظة مع المعلمين - انقطاع الاتصال الالكتروني فى بعض الأوقات خلال التطبيق.

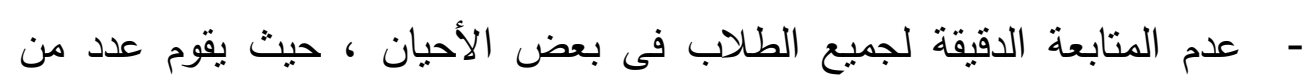

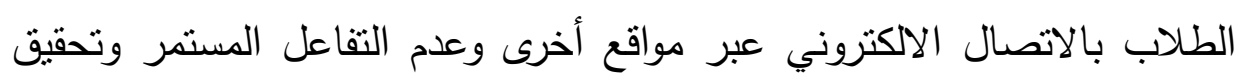
الاندماج الكامل مع المعلم طوال فترة التطبيق العملى والفعلى. - ضعف المستوى المعرفي الإلكتروني لعدد من المعلمين بالمعرفة الكافية بتقنيات

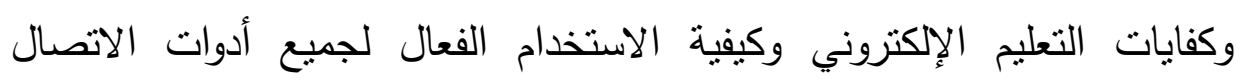




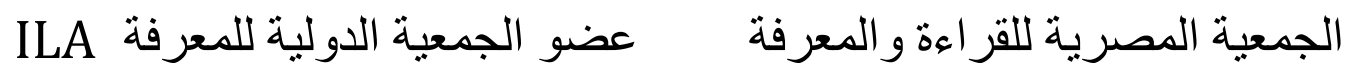

التزامنى المباشر (مثل غرف الحوار المباشر) مع الطلاب وكذلك أدوات الاتصال اللاتزامنى عبر الانترنت ( مثل البريد الإلكتروني ) مع الطلاب.

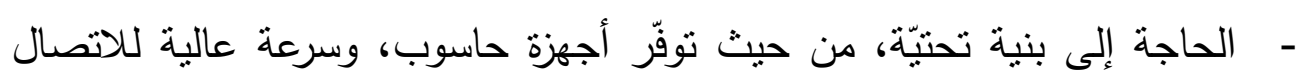
بالإنترنت.

- إضعاف دافعيّة الطلاب نحوَ التعلّم، بسبب قضاء الكثير من الوقت أمام شاثنة الحاسوب والمواقع الإكترونيّة.

- صعوبة التقييم وتطوير معاييره وليس هناك مجال لمناقثة الإجابة أو فهمها بطريقة مختلفة

- وجود عددٍ كبير من المعلمين الحاليين غير قادرين على استخدام التقنية الرقيّة بطريقة تمكّنهم من التعامل معها، والتدريس من خلالها، لذا لا بدّ من عقد دوراتٍ

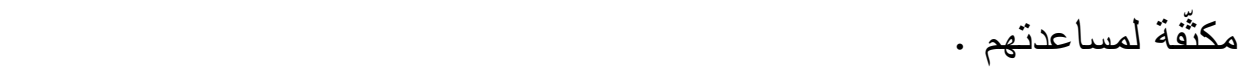
ثانيًا : تطبيق كفايات التعليم الإكتروني لدى طلاب ومعلمي الأحياء في المرحلة الثانوية

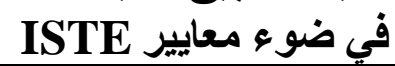

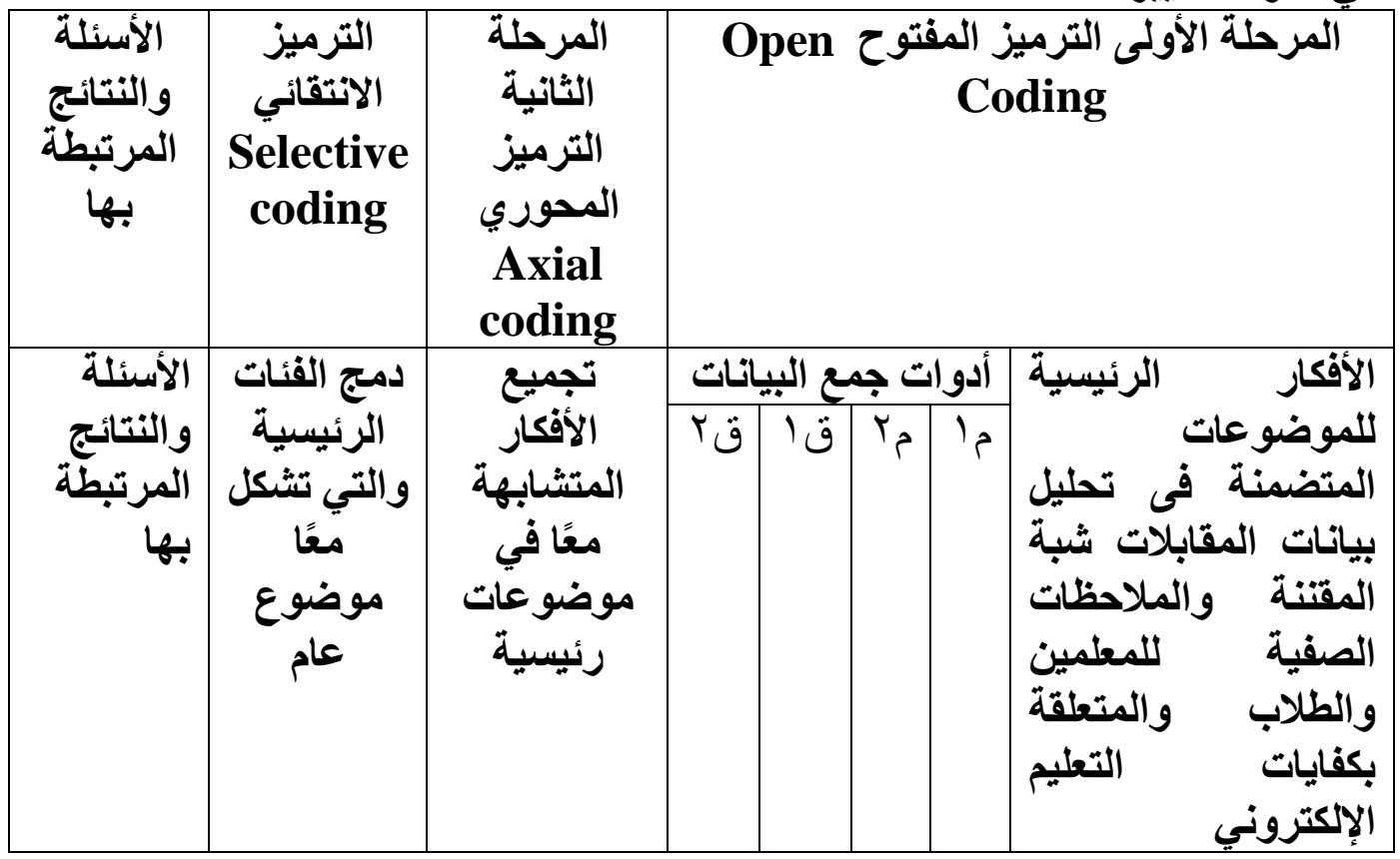




\section{الجمعية المصرية للقر اعة و المعرفة عضو الجمعية الدولية للمعرفة ILA}

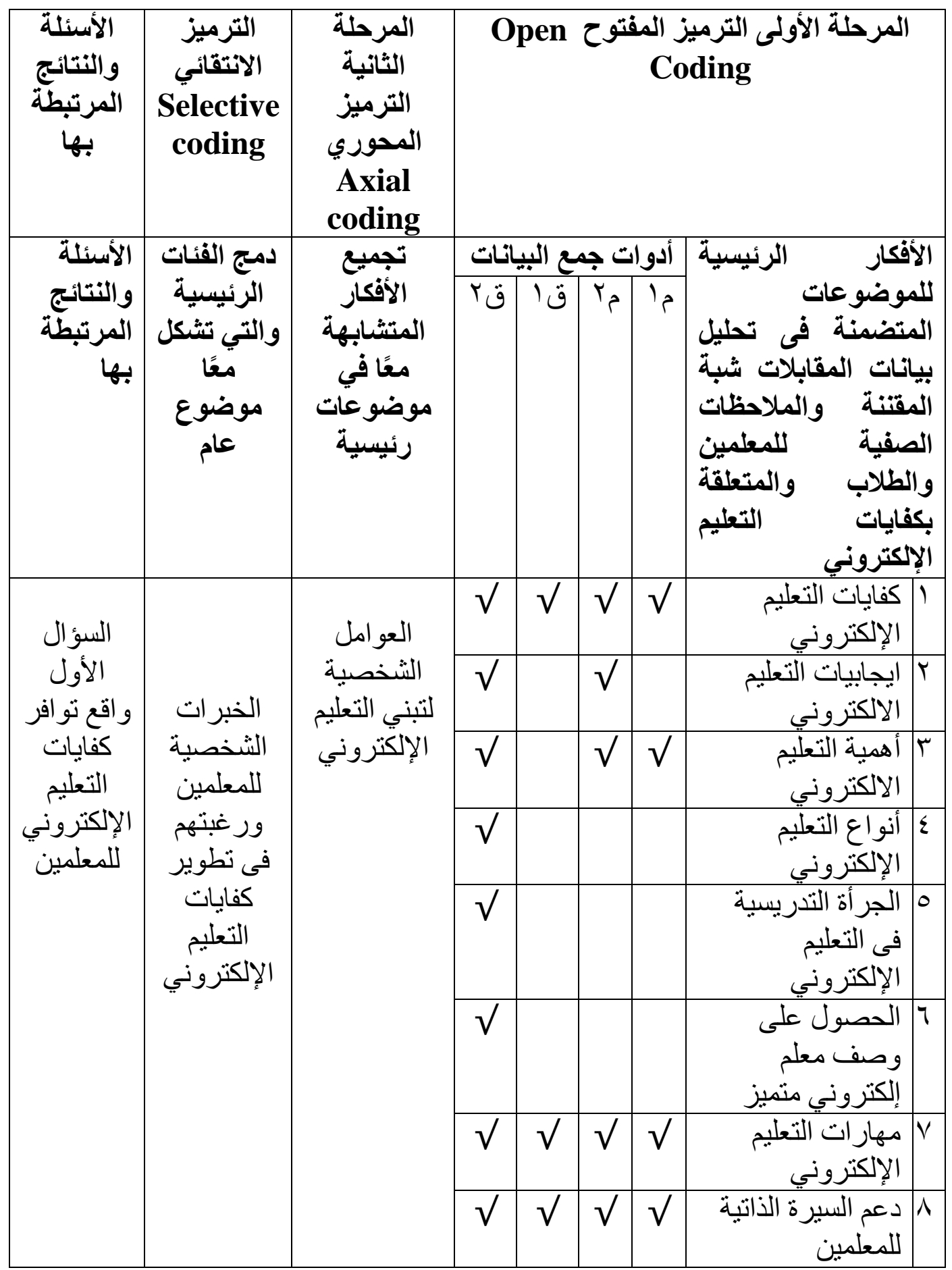




\section{الجمعية المصرية للقر اعة و المعرفة عضو الجمعية الدولية للمعرفة ILA}

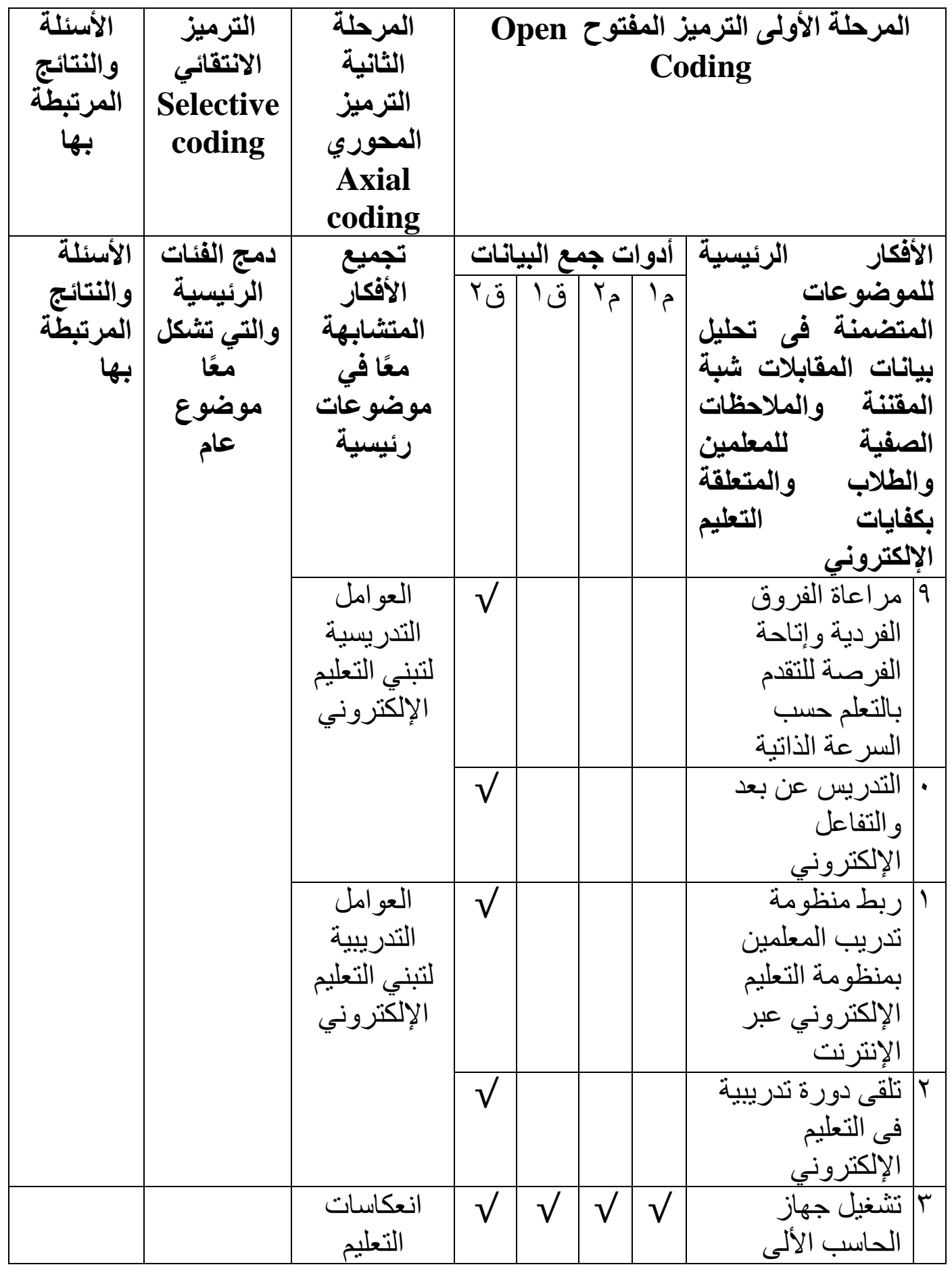




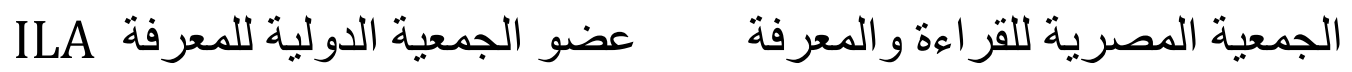

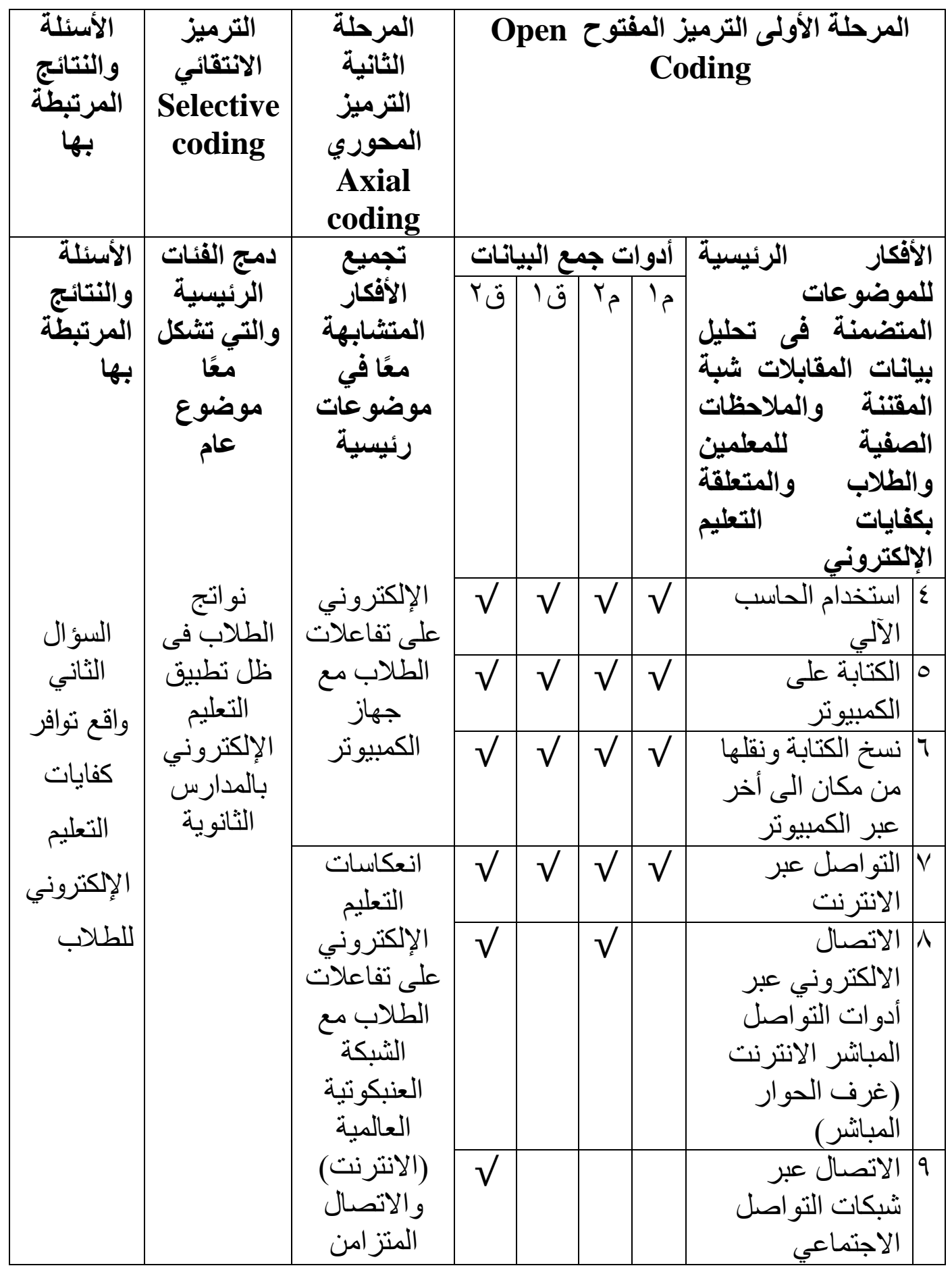




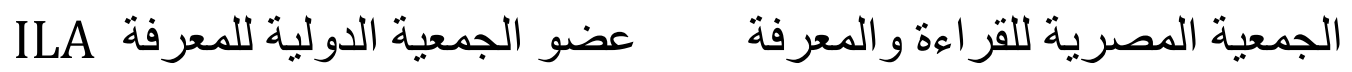

\begin{tabular}{|c|c|c|c|c|c|c|c|c|}
\hline والأسئلة & الانتقائيز & الثرحلة الثانية & \multicolumn{6}{|c|}{$\begin{array}{c}\text { Open المرحلة الأولى الترميز المفتوح } \\
\text { Coding }\end{array}$} \\
\hline بها & coding & $\begin{array}{l}\text { المحوري } \\
\text { Axial } \\
\text { coding }\end{array}$ & & & & & & \\
\hline \multirow{12}{*}{ الأسئلة } & \multirow{12}{*}{ والرئيسية الفئات } & \multirow{12}{*}{ 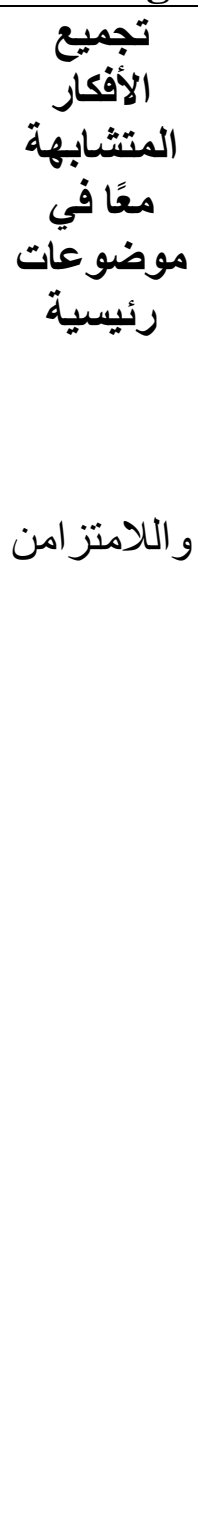 } & \multicolumn{4}{|c|}{ أدوات جمع البيانات } & \multirow{2}{*}{\multicolumn{2}{|c|}{ للموضو الأفكار }} \\
\hline & & & \multirow[t]{4}{*}{ قr } & \multirow[t]{4}{*}{ ق } & \multirow[t]{4}{*}{$t^{5}$} & \multirow[t]{4}{*}{ 15 } & & \\
\hline & & & & & & & \multirow{3}{*}{\multicolumn{2}{|c|}{ 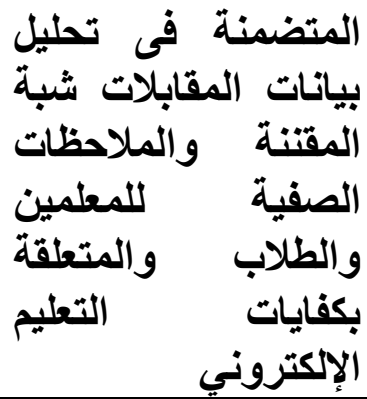 }} \\
\hline & & & & & & & & \\
\hline & & & & & & & & \\
\hline & & & $\sqrt{ }$ & $\sqrt{ }$ & $\sqrt{ }$ & $\sqrt{ }$ & |الإنتراملت مع شبكة & . \\
\hline & & & $\sqrt{ }$ & $\sqrt{ }$ & $\sqrt{ }$ & $\sqrt{ }$ & | الكمبيونر الملف على & 1 \\
\hline & & & $\sqrt{ }$ & $\sqrt{ }$ & $\sqrt{ }$ & $\sqrt{ }$ & |الانترنت الملف على & r \\
\hline & & & $\sqrt{ }$ & $\sqrt{ }$ & $\sqrt{ }$ & $\sqrt{ }$ & | البريدام ملفات عبر الإكتروني & r \\
\hline & & & $\sqrt{ }$ & $\sqrt{ }$ & $\sqrt{ }$ & $\sqrt{ }$ & التين الطاعل و التو اصلب عبر الإلكتروني & $\varepsilon$ \\
\hline & & & $\sqrt{ }$ & & & & 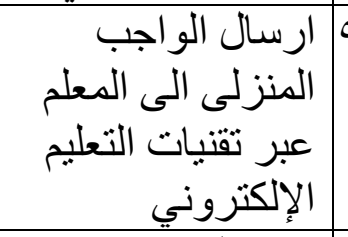 & 0 \\
\hline & & & $\sqrt{ }$ & & & $\sqrt{ }$ & 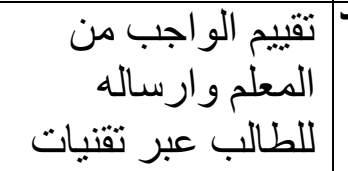 & 7 \\
\hline
\end{tabular}




\section{الجمعية المصرية للقر اعة و المعرفة عضو الجمعية الدولية للمعرفة ILA}

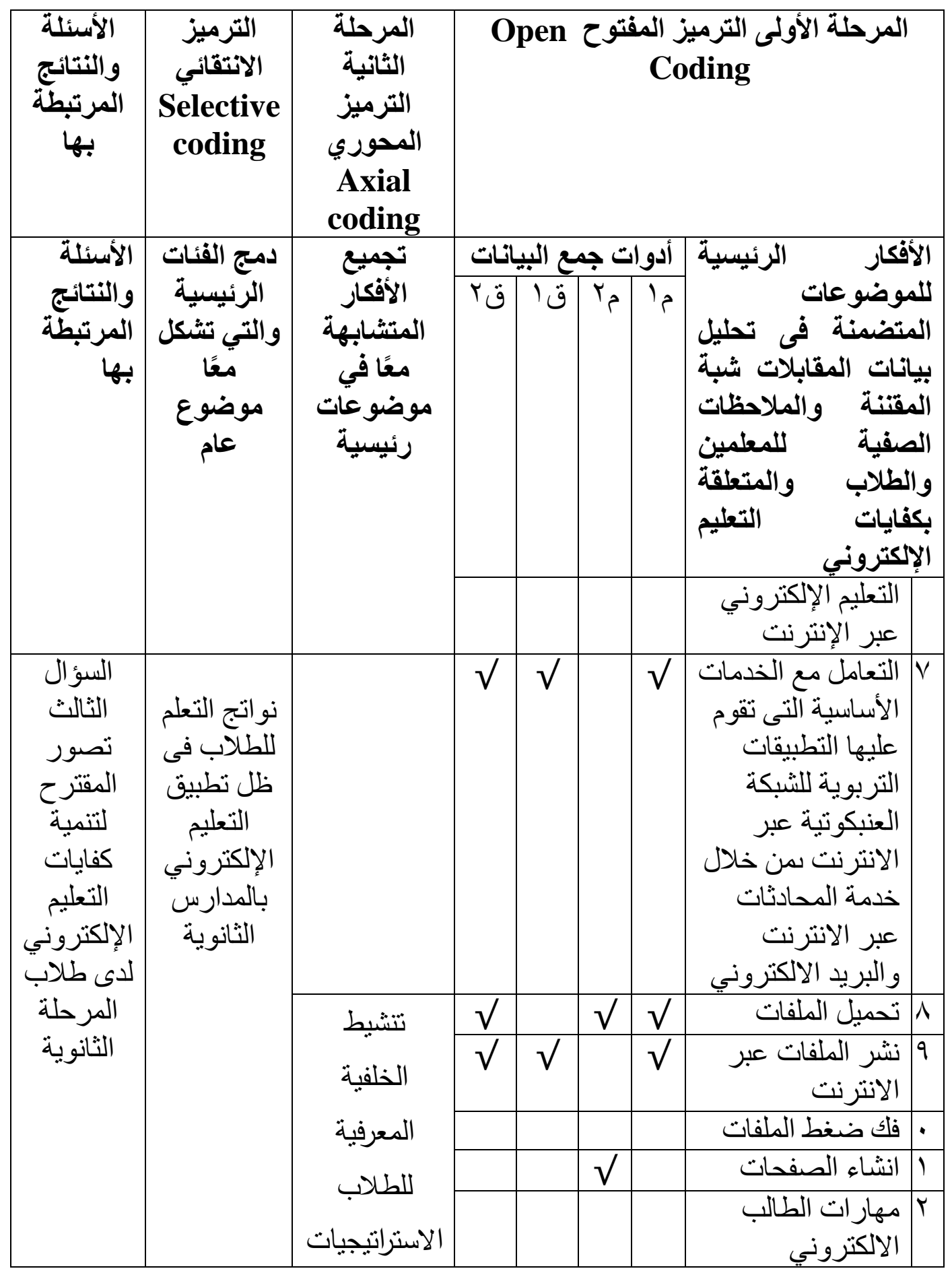




\section{الجمعية المصرية للقر اعة و المعرفة عضو الجمعية الدولية للمعرفة ILA}

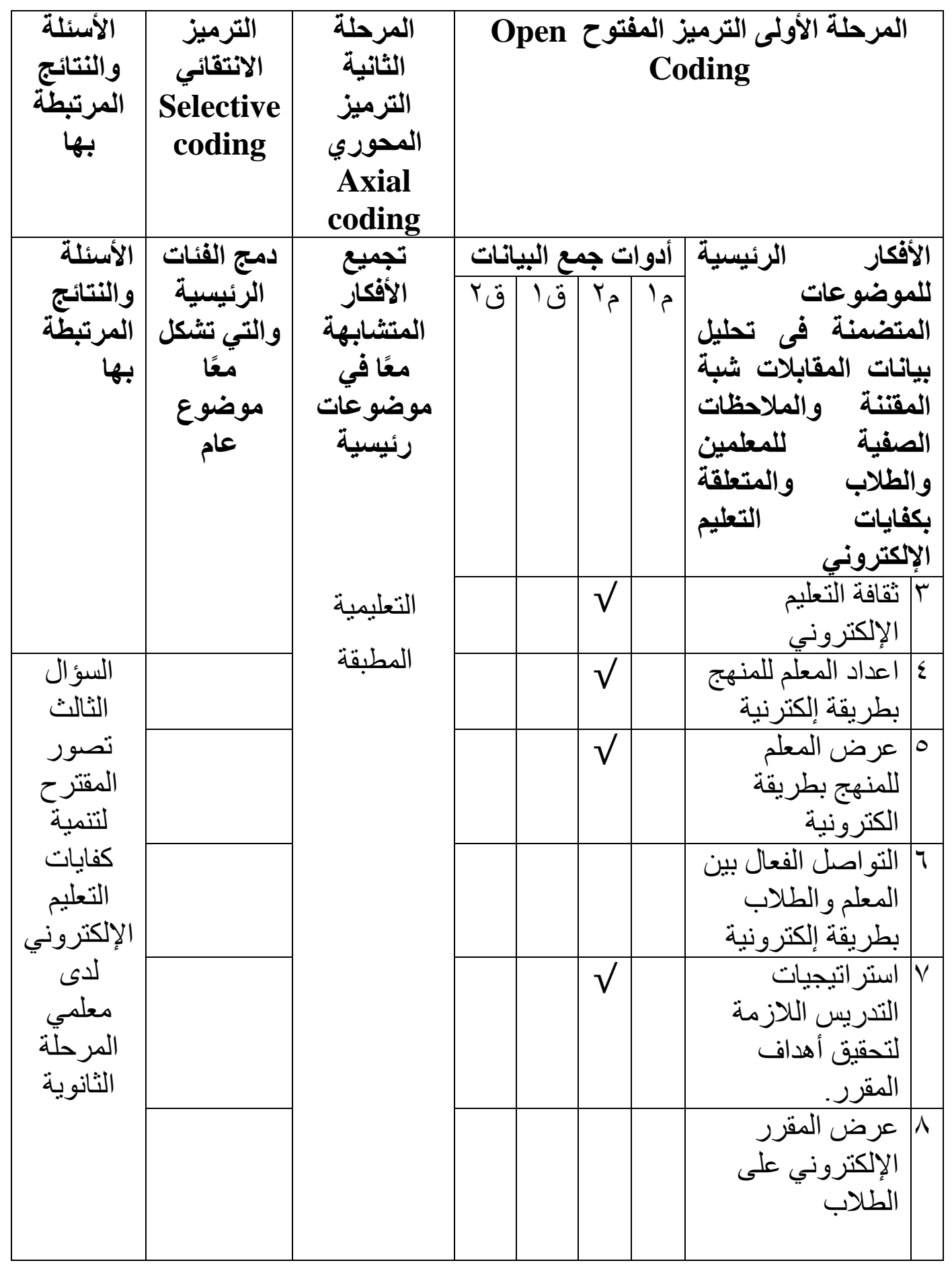




\section{الجمعية المصرية للقر اعة و المعرفة عضو الجمعية الدولية للمعرفة ILA}

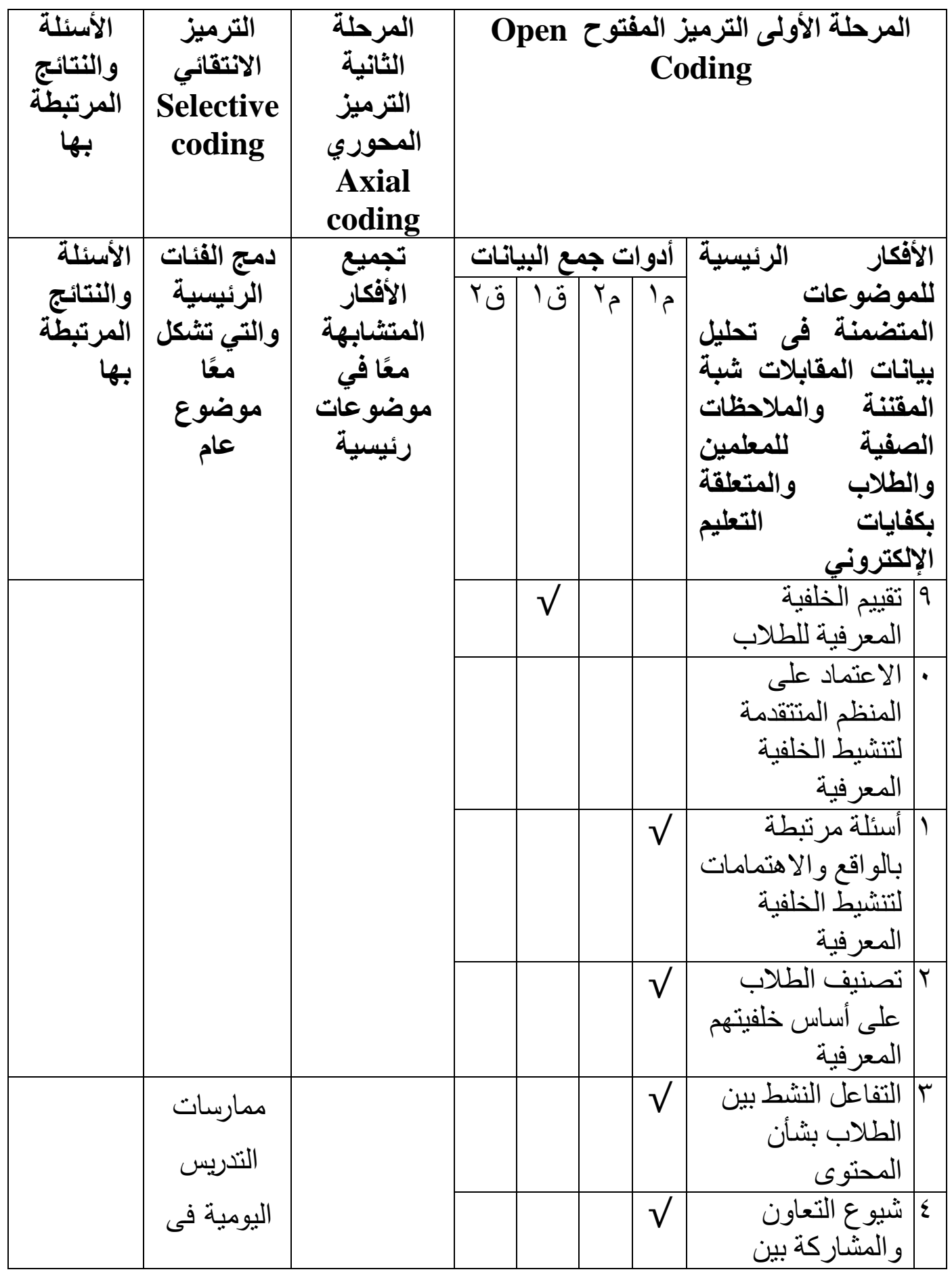




\section{الجمعية المصرية للقر اعة و المعرفة عضو الجمعية الدولية للمعرفة ILA}

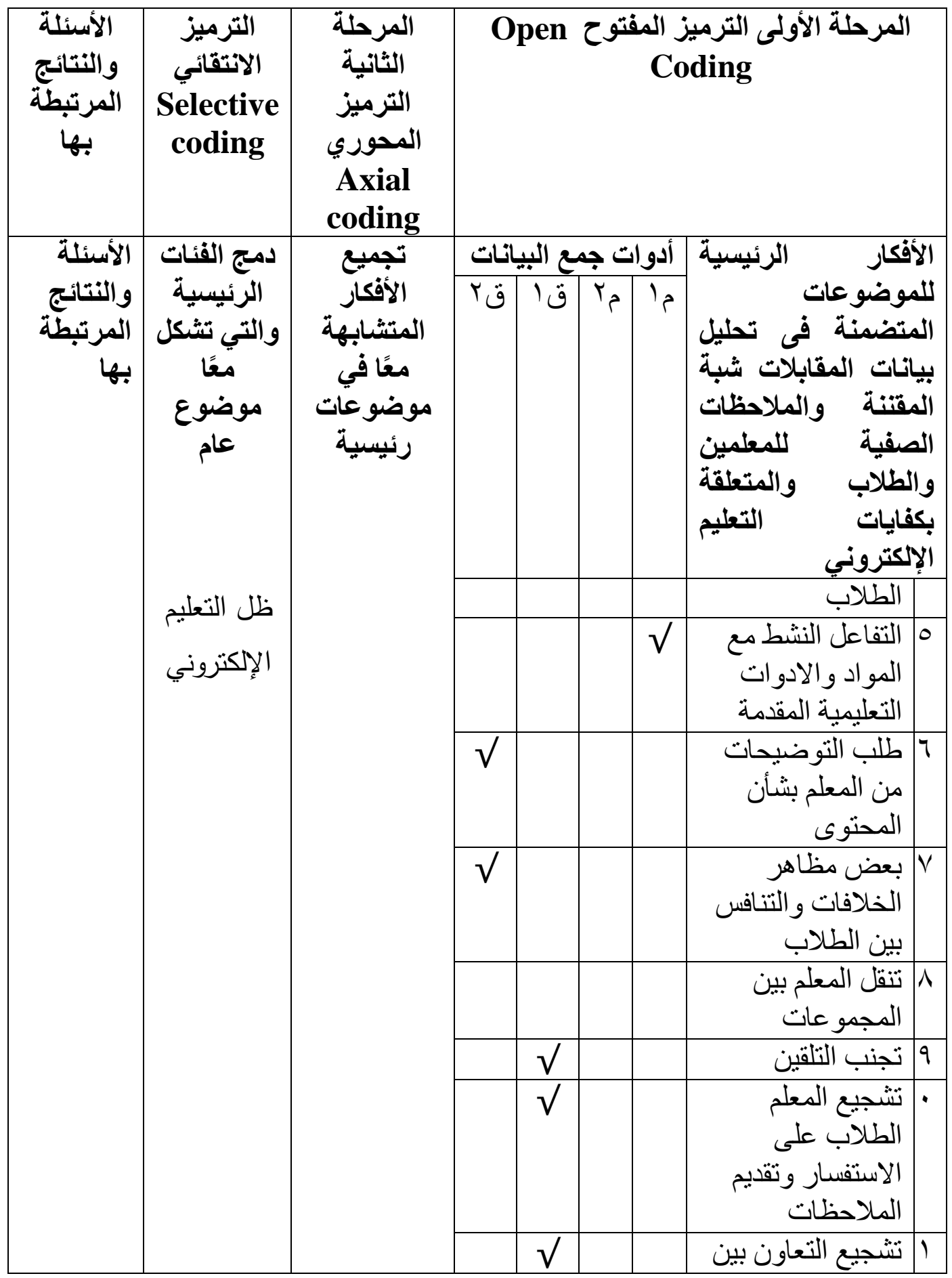




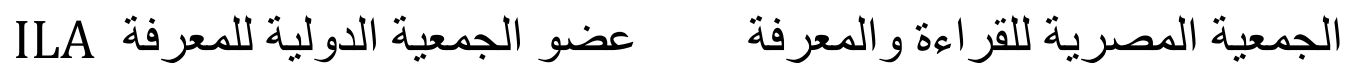

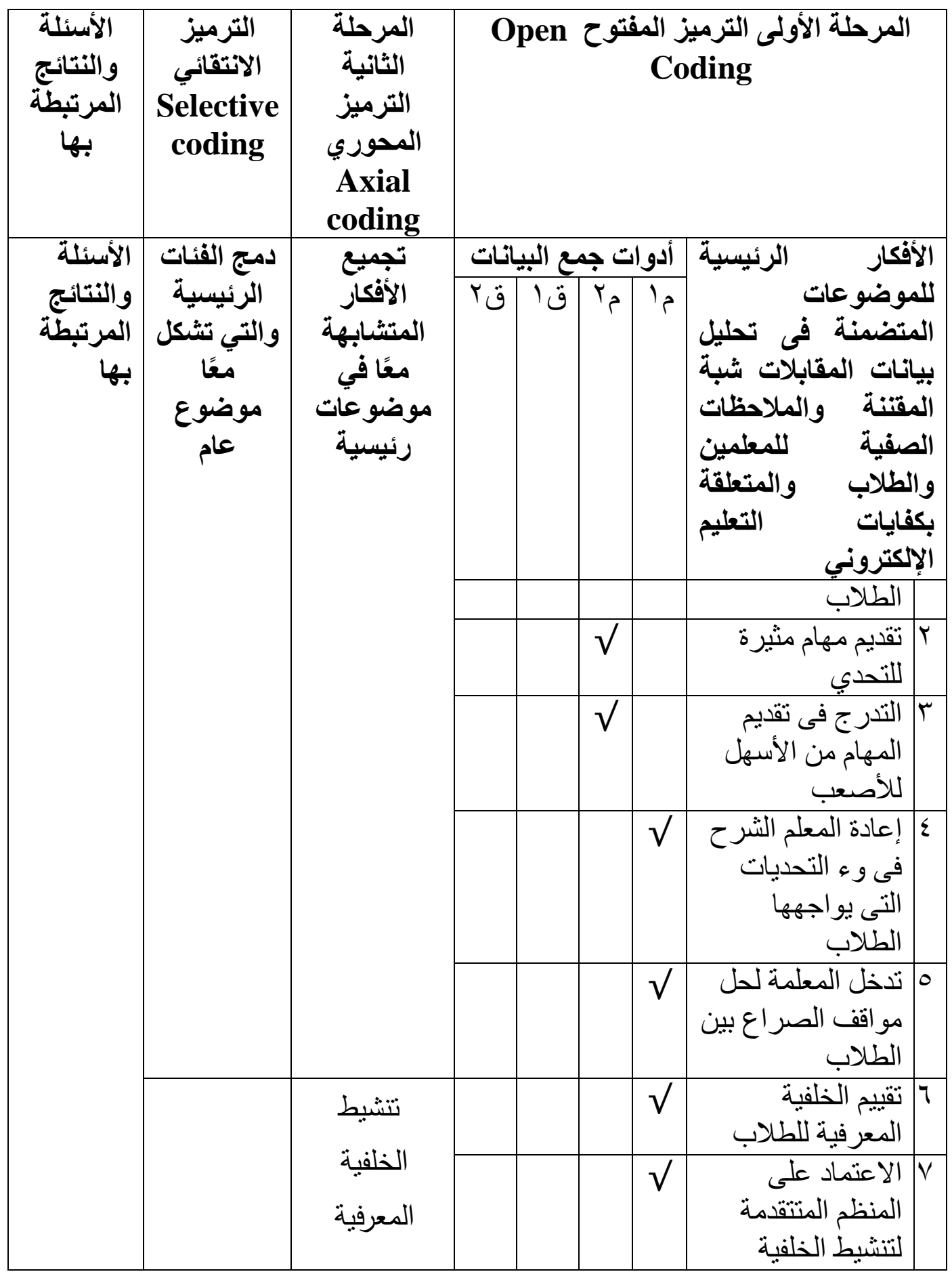




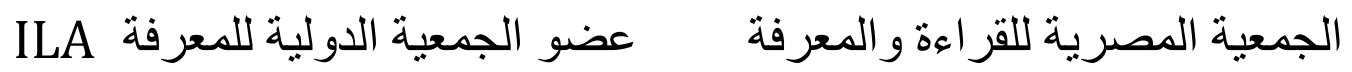

\begin{tabular}{|c|c|c|c|c|c|c|c|}
\hline والأسئلة & الانتقائيز & الثرحية & \multicolumn{5}{|c|}{$\begin{array}{c}\text { Open المرحلة الأولى الترميز المفتوح } \\
\text { Coding }\end{array}$} \\
\hline بها & coding & $\begin{array}{l}\text { المحوري } \\
\text { Axial } \\
\text { coding }\end{array}$ & & & & & \\
\hline \multirow{11}{*}{ الأسئلة } & \multirow{7}{*}{ دالرئيسية الفئات } & \multirow{7}{*}{ 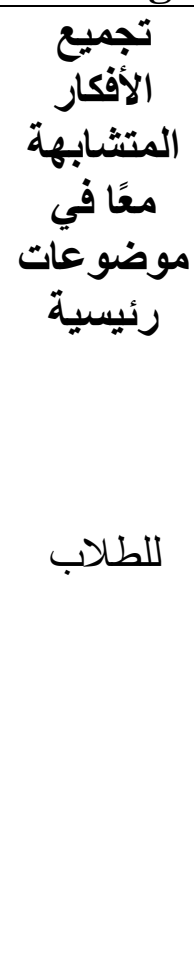 } & \multicolumn{4}{|c|}{ أدوات جمع البيانات } & \multirow{2}{*}{ للموضو الأفكار $\quad$ الرئيسية } \\
\hline & & & \multirow[t]{3}{*}{ ق ق } & \multirow[t]{3}{*}{ ق } & \multirow[t]{3}{*}{$t^{5}$} & \multirow[t]{3}{*}{ 15 } & \\
\hline & & & & & & & \multirow{2}{*}{ 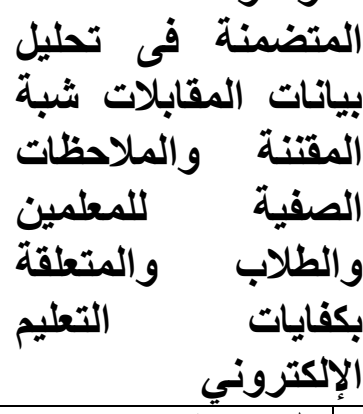 } \\
\hline & & & & & & & \\
\hline & & & & & & & المعرفية \\
\hline & & & & $\sqrt{ }$ & & & 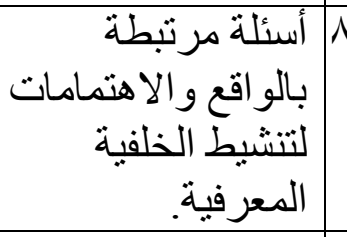 \\
\hline & & & & $\sqrt{ }$ & & & 9 \\
\hline & & & & $\sqrt{ }$ & & & • \\
\hline & & & & & $\sqrt{ }$ & & ' 1 تحمس الطلاب \\
\hline & & & & & & $\sqrt{ }$ & با التعلم العميق \\
\hline & & & & & & $\sqrt{ }$ & ץ' الطسين اتجاهات \\
\hline
\end{tabular}




\section{الجمعية المصرية للقر اعة و المعرفة عضو الجمعية الدولية للمعرفة ILA}

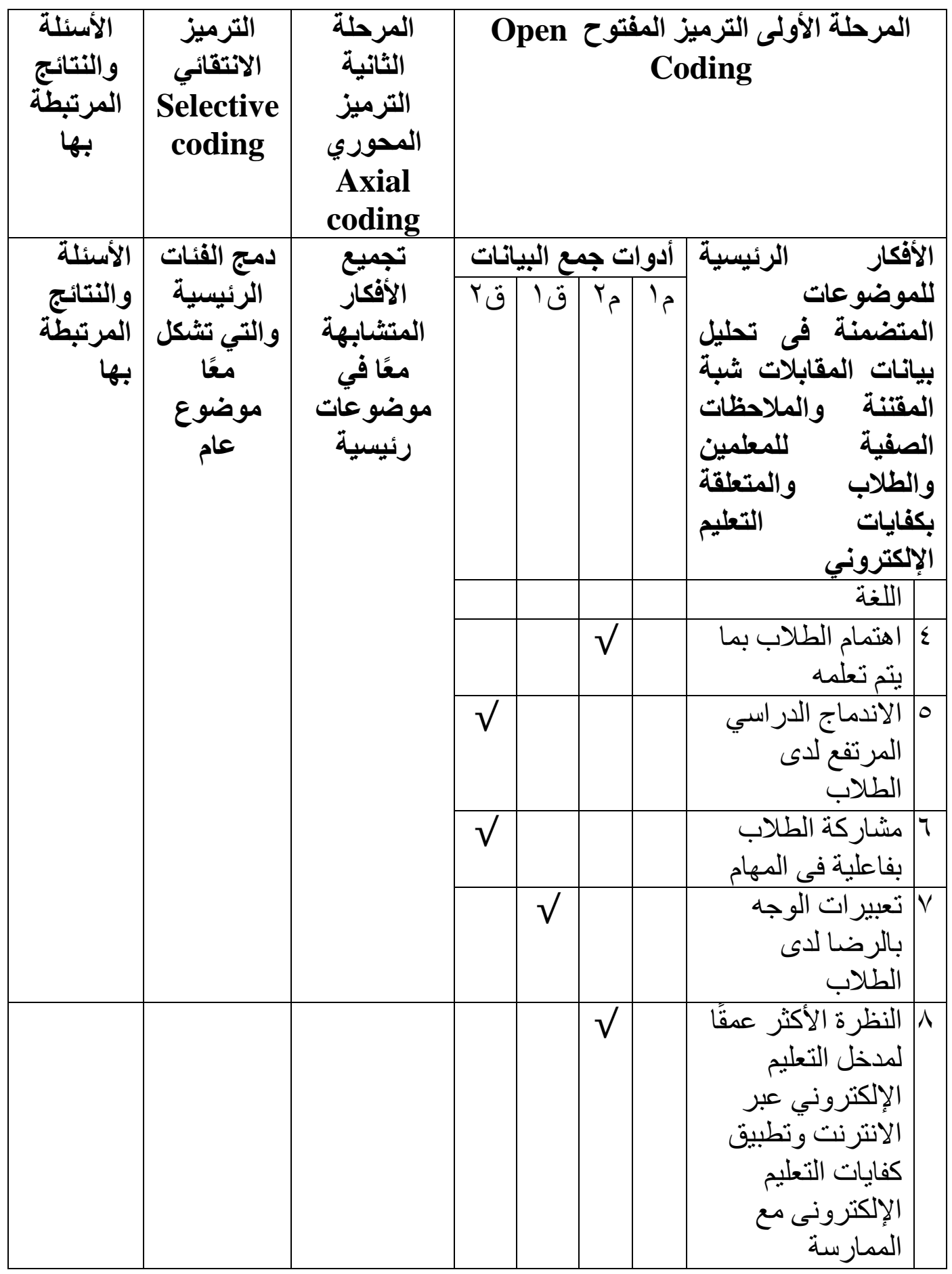




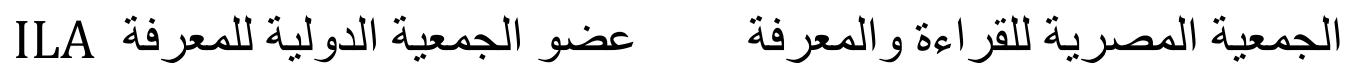

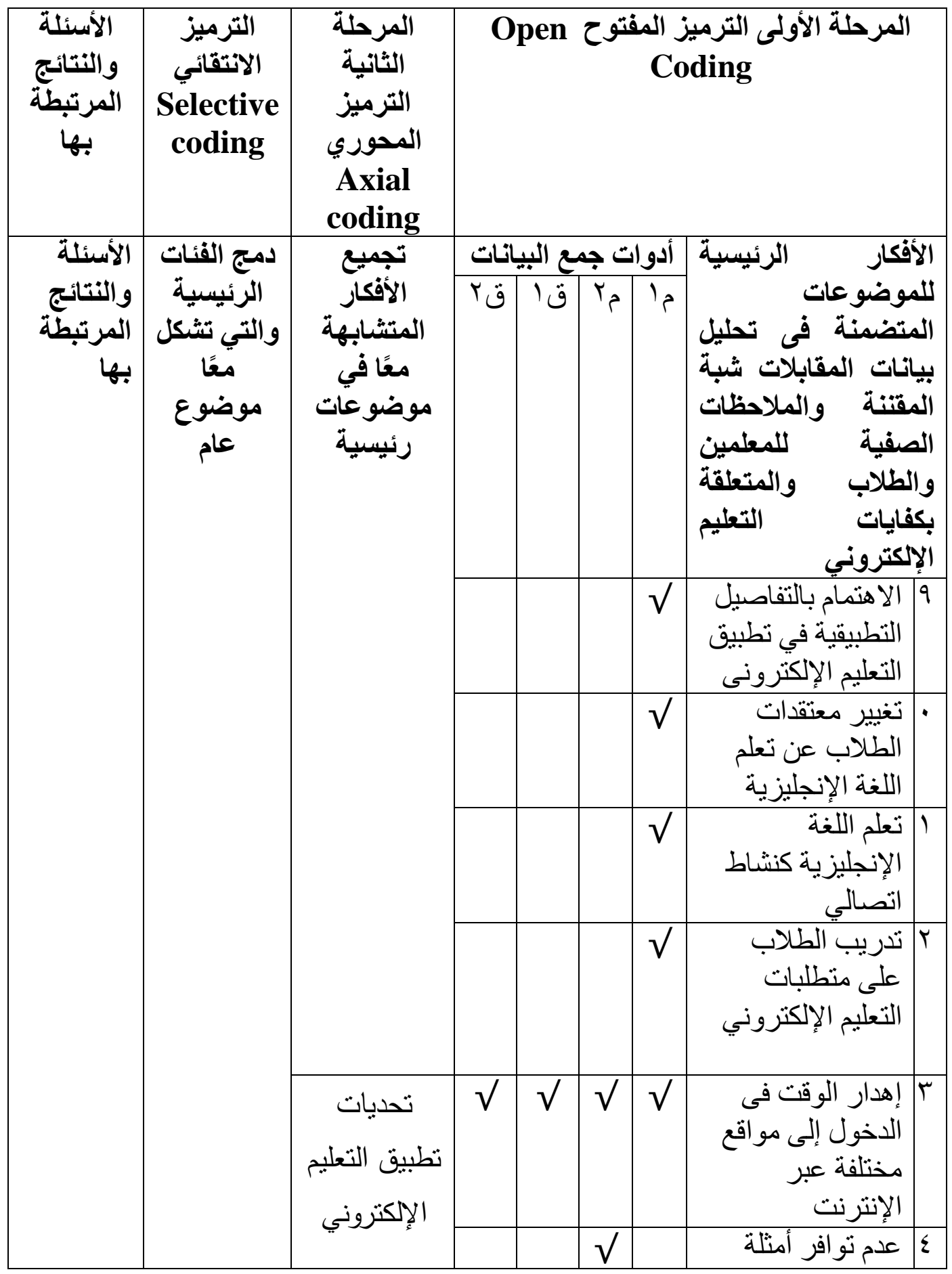




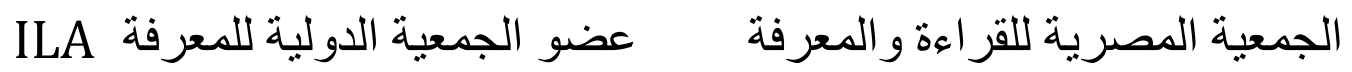

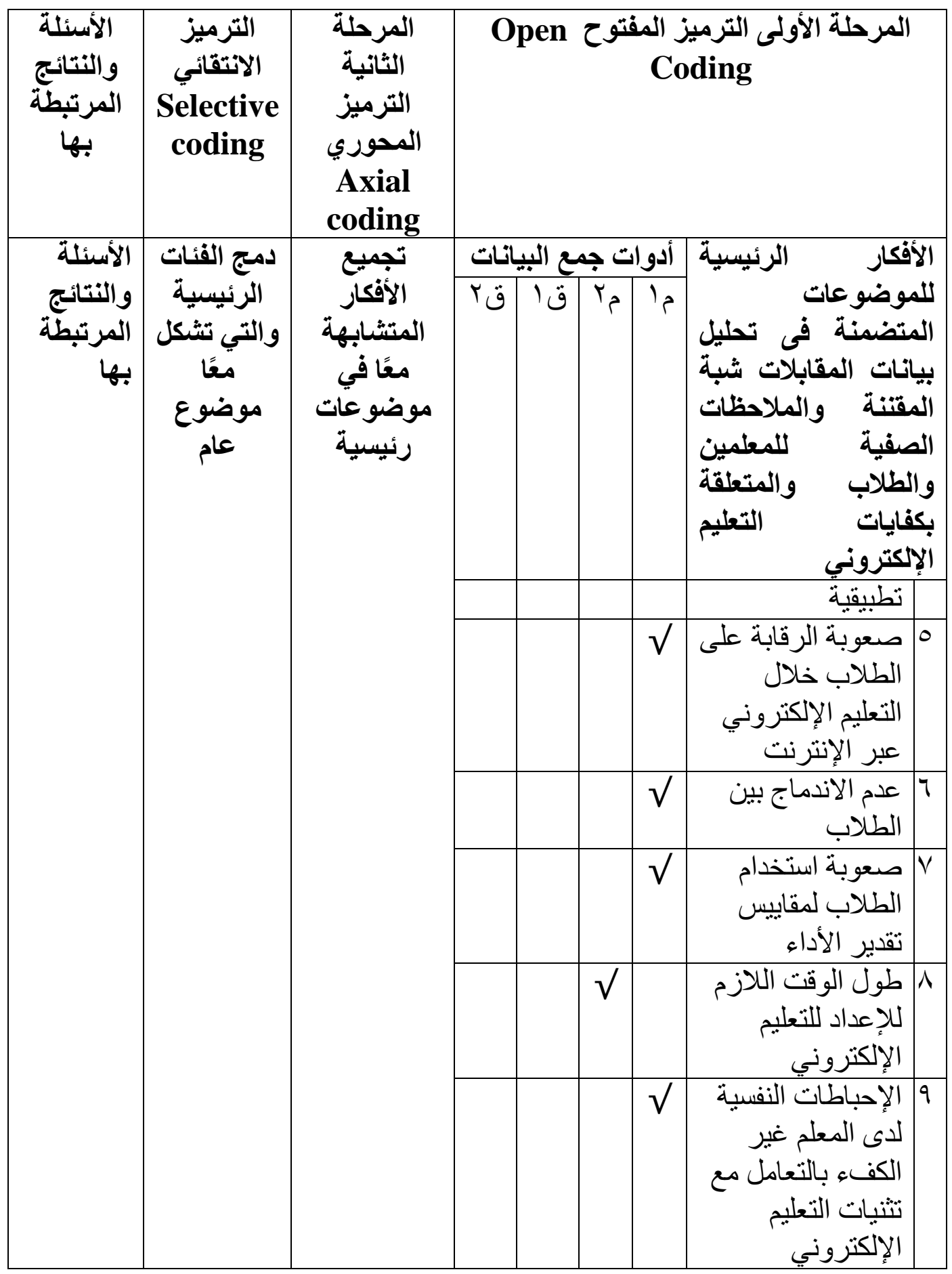




\section{الجمعية المصرية للقر اعة و المعرفة عضو الجمعية الدولية للمعرفة ILA}

\begin{tabular}{|c|c|c|c|c|c|c|c|c|}
\hline والأسئلة & الانتثائيز & الثرحلة الثانية & \multicolumn{6}{|c|}{$\begin{array}{c}\text { Open المرحلة الأولى الترميز المفتوح } \\
\text { Coding }\end{array}$} \\
\hline بها & coding & $\begin{array}{l}\text { المحوري } \\
\text { Axial } \\
\text { coding }\end{array}$ & & & & & & \\
\hline \multirow{9}{*}{ الأسئلة } & \multirow{6}{*}{ دالتئيسئة الفئات } & \multirow{6}{*}{ 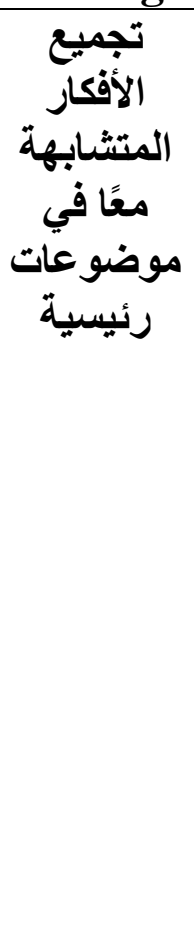 } & \multicolumn{4}{|c|}{ أدوات جمع البيانات } & \multirow{2}{*}{\multicolumn{2}{|c|}{ للموضو عات الأفكار }} \\
\hline & & & \multirow[t]{3}{*}{ ق قr } & \multirow[t]{3}{*}{ ق } & \multirow[t]{3}{*}{$t^{5}$} & \multirow[t]{3}{*}{ م5 } & & \\
\hline & & & & & & & \multirow{2}{*}{\multicolumn{2}{|c|}{ 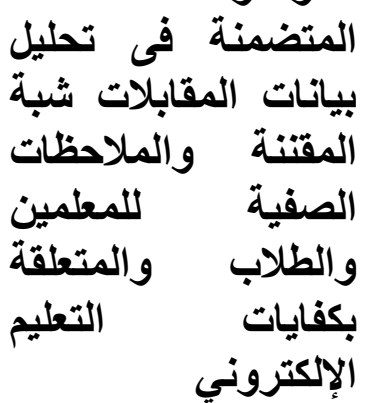 }} \\
\hline & & & & & & & & \\
\hline & & & & & & $\sqrt{ }$ & كثرة سؤ ال الطلاب & . \\
\hline & & & & & & $\sqrt{ }$ & | علدم اعتياد الطلاب طريقة التعليم & 1 \\
\hline & & & & $\sqrt{ }$ & $\sqrt{ }$ & $\sqrt{ }$ & 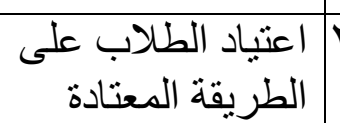 & r \\
\hline & & تطبيت & & & & $\sqrt{ }$ & | لتطبيق التعليم الطلاب & $\mu$ \\
\hline & & الت الإكتروني & & & & $\sqrt{ }$ & اللطعارض الأدوار المتعددة بين & \\
\hline
\end{tabular}




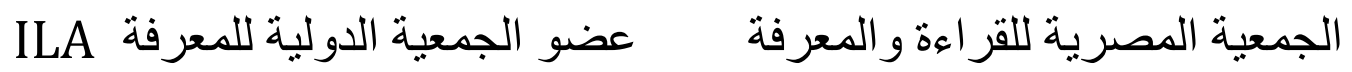

\begin{tabular}{|c|c|c|c|c|c|c|c|c|}
\hline والأسئلة & $\begin{array}{c}\text { الانتقائيز } \\
\text { Selective } \\
\text { coding }\end{array}$ & $\begin{array}{c}\text { المرحلة الثرميزة } \\
\text { الثردية } \\
\text { Axial } \\
\text { coding }\end{array}$ & \multicolumn{6}{|c|}{$\begin{array}{c}\text { Open المرحلة الأولى الترميز المفتوح } \\
\text { Coding }\end{array}$} \\
\hline \multirow{8}{*}{ الأسئلة } & \multirow{8}{*}{ والرئيسية الفئات } & \multirow{8}{*}{ موضنا } & \multicolumn{4}{|c|}{ أدوات جمع البيانات } & \multicolumn{2}{|l|}{ الأفكار لرئيسية } \\
\hline & & & ق & ق & $r^{5}$ & م1 & \multicolumn{2}{|l|}{ 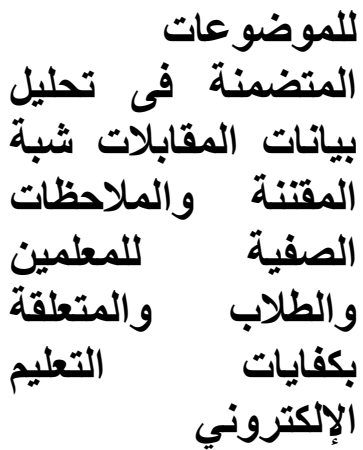 } \\
\hline & & & & & & $\sqrt{ }$ & | صعوبة استخدام & \\
\hline & & & & & & $\sqrt{ }$ & | الطعاب لبعض تنفيذ & 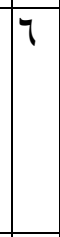 \\
\hline & & & & & & $\sqrt{ }$ & 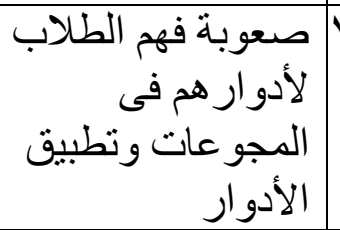 & \\
\hline & & & & & & $\sqrt{ }$ & 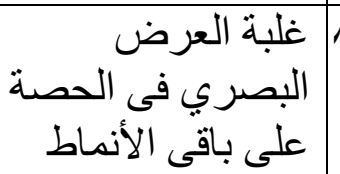 & \\
\hline & & & & & & $\sqrt{ }$ & | شيوع النمط المعتاد & \\
\hline & & & $\sqrt{ }$ & $\sqrt{ }$ & $\sqrt{ }$ & $\sqrt{ }$ & |الاعتماد على & $\cdot$ \\
\hline
\end{tabular}




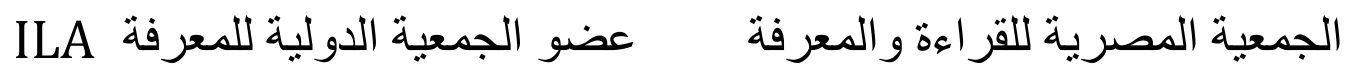

\begin{tabular}{|c|c|c|c|c|c|c|c|c|}
\hline والأسئلة & الانتقائيز & الثرحية & \multicolumn{6}{|c|}{$\begin{array}{c}\text { Open المرحلة الأولى الترميز المفتوح } \\
\text { Coding }\end{array}$} \\
\hline بها & coding & $\begin{array}{c}\text { المحوري } \\
\text { Axial } \\
\text { coding }\end{array}$ & & & & & & \\
\hline \multirow{10}{*}{ الأسئلة } & \multirow{10}{*}{ دالرئيسية الفئات } & \multirow{5}{*}{ 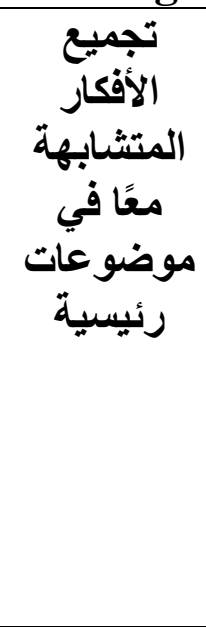 } & \multicolumn{4}{|c|}{ أدوات جمع البيانات } & \multicolumn{2}{|l|}{ الأفكار الرئيسية } \\
\hline & & & \multirow[t]{3}{*}{ ق } & \multirow[t]{3}{*}{ ق } & \multirow[t]{3}{*}{$t^{5}$} & \multirow[t]{3}{*}{ 15 } & \multirow{3}{*}{\multicolumn{2}{|c|}{ المبات المتضمنة }} \\
\hline & & & & & & & & \\
\hline & & & & & & & & \\
\hline & & & & & & & والقتبار ات الورقة & \\
\hline & & سبل التغلب & $\sqrt{ }$ & $\sqrt{ }$ & $\sqrt{ }$ & $\sqrt{ }$ & |الإلكترونية تطبيق التحليم & 1 \\
\hline & & التحديات & $\sqrt{ }$ & $\sqrt{ }$ & $\sqrt{ }$ & $\sqrt{ }$ & | التعسب لتطبيق الإكتروني & $r$ \\
\hline & & & $\sqrt{ }$ & $\sqrt{ }$ & $\sqrt{ }$ & $\sqrt{ }$ & الإلكتبرونيق التعليم الكامل & $r$ \\
\hline & & & $\sqrt{ }$ & $\sqrt{ }$ & $\sqrt{ }$ & $\sqrt{ }$ & مع جميع الطعلابت الاكترونى تطبيق & $\varepsilon$ \\
\hline & & & $\sqrt{ }$ & $\sqrt{ }$ & $\sqrt{ }$ & $\sqrt{ }$ & 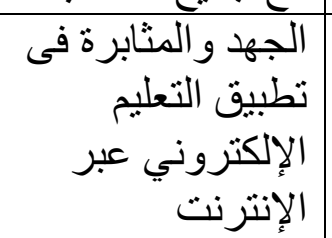 & 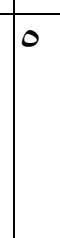 \\
\hline
\end{tabular}




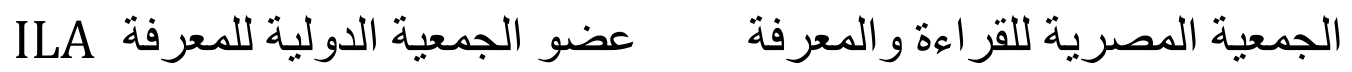

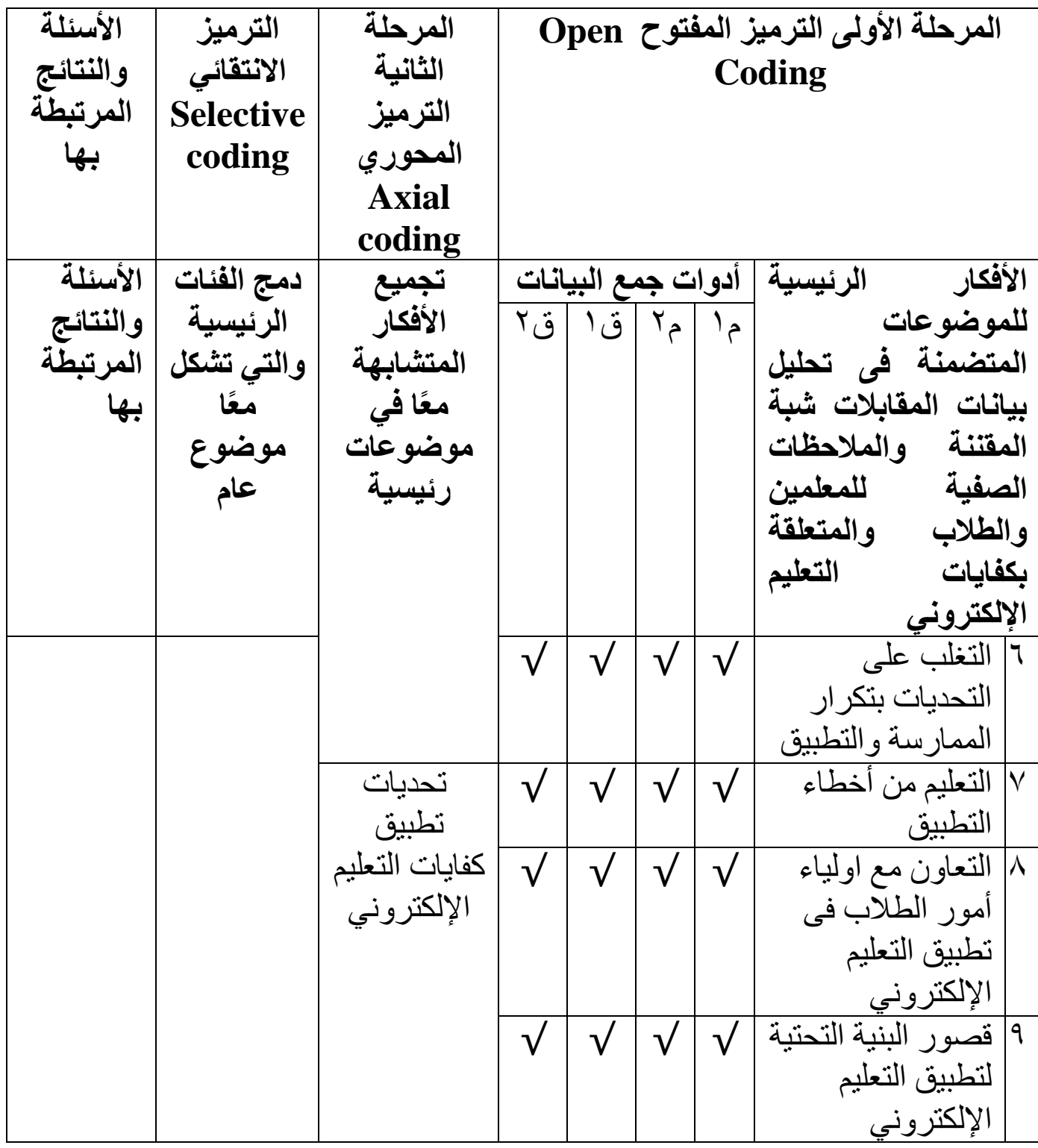

المراجع العربية والأجنبية والإنترنت

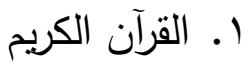

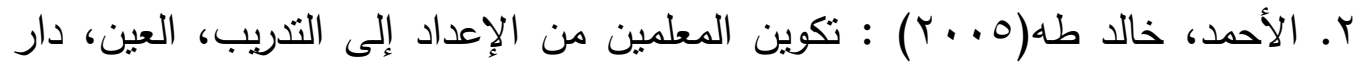

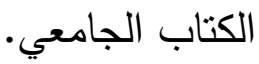




\section{الجمعية المصرية للقر اعة والمعرفة عضو الجمعية الدولية للمعرفة}

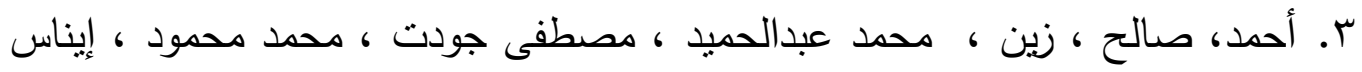

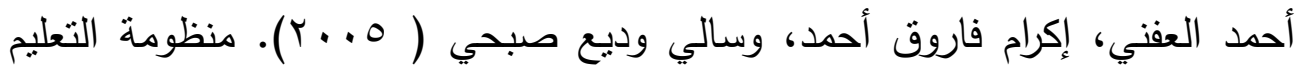
عبر الثبكات، تحرير : محمد عبد الحميد، القاهرة: عالم الكتب.

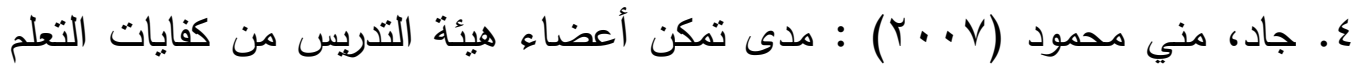

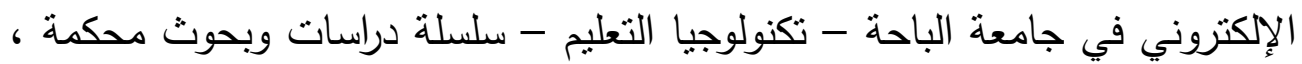

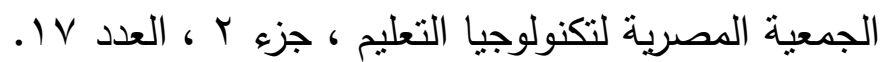

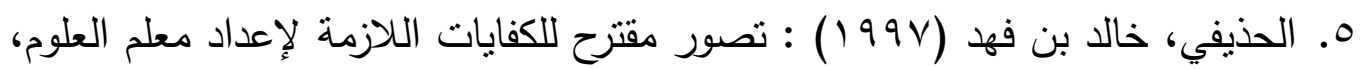
دكتوراه غير منشورة، كلية التربية، جامعة عين شمس، القاهزة.

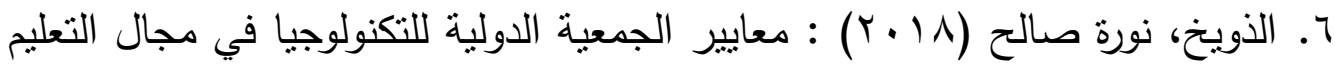

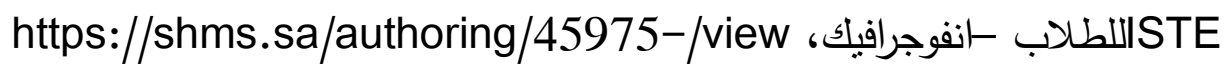
V. الثعوان، عبد الرحمن (.99) الكفايات التعليمية لطلبة كلية التربية بالمملكة العربية

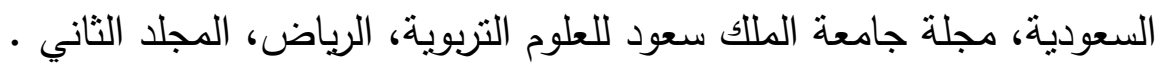

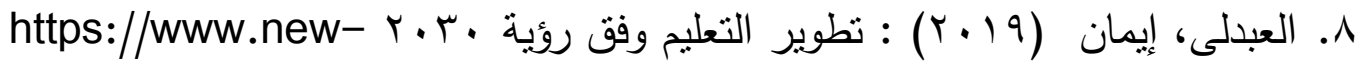
educ.com/ -2030

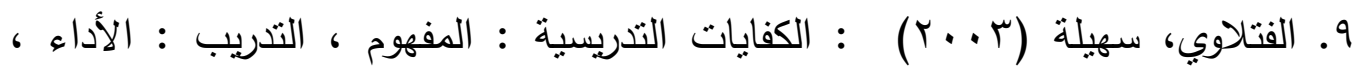

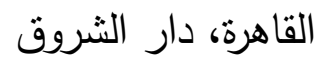
•. الموسي، عبداله عبدالعزيز ، المبارك ، أحمد عبدالعزيز (0.0 ب) التعليم

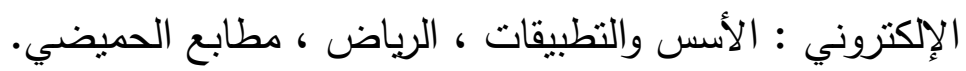

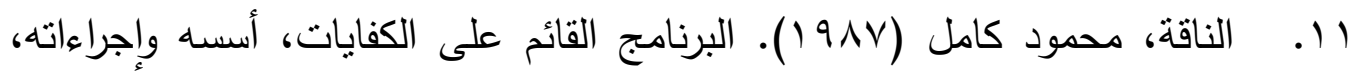
القاهرة ، مطابع الطوبجي.

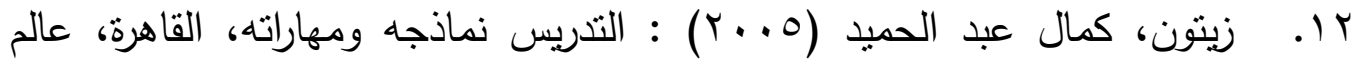




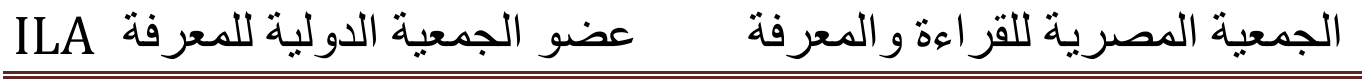

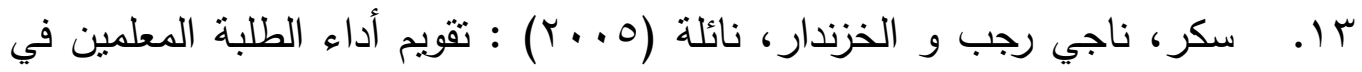
كليات التربية بجامعة الأقصى في ضوء كفايات لازمة لمعلم المستقبل، مجلة التربية العلمية، الجمعية المصرية للتربية العلمية، المجلد الثامن، العدد الرابع، كلية التربية جامعة عين شمس، ديسمبر . 2005

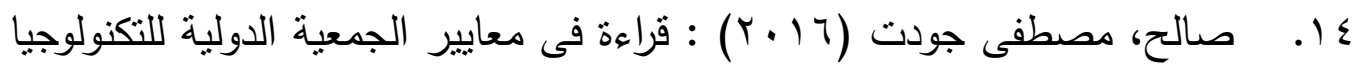
https://drgawdat.edutech-portal.net/archives/15562 فى التعليم 1. . عبد المنعم، على محمد (99V (1). تكنولوجيا التعليم والوسائل التعليمية، القاهرة: دار البشرى للطباعة والنشر • - النش

1 ا. عبداللاه، كريمة محمود محمد (2016) : تصور مقترح لتطوير كفايات التعلم الإكتروني اللازمة لتدريس الفيزياء لدى معلمات المرحلة الثانوية ، بحث منشور

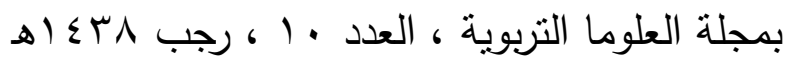

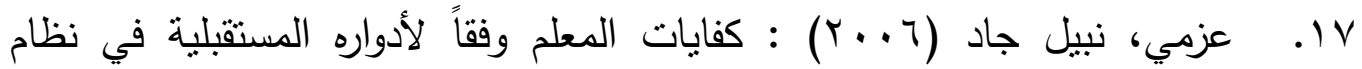
التعليم الإلكتروني عن بعد "، المؤتمر الدولي للتعلم من بعد، مسقط: سلطنة عمان،

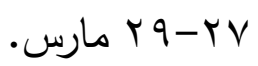

1 ا. مرعى، توفيق، شرح الكفايات التعليمية، عمان الأردن، دار الفرقان للنشر والتوزيع، r. r.

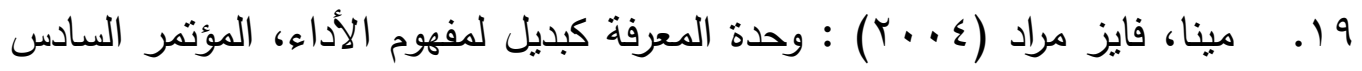
عشر الجمعية المصرية للمناهج وطرق التدريس (تكوين المعلم)، المجلد الأول، القاهرة، دار الضيافة جامعة عين شمس، ع . . ب م. 
20.Birch, P.D.(2002) • " E-Learner Competencies", Available At: http://www.learningcircuits.org/2002/jul2002/birch.html

21. Sanders, E. S.(2001). " E-Learning Competencies", Available At: http://www.learningcircuits.org/2001/mar2001/competencies.html

22. Spector, J. M. \& Teja, I., D.(2001). " Competencies for Online Teaching ", U.S. Department of Education, ED 99-co-0005.

23. Web (2007). " The eLearning Competency Framework for Teachers and

Trainers",http://www.oph.fi/attachment.asp?/path=1,439.3739.7557. $\underline{384043}$

24. - Web (2007). " Educational Technology Standards and Performance Indicators for All Teachers", http://cents.iste.org/ncate/n_found.html

25. http://mohamoonksa.com/default.aspx?action=PREVIEW_CONTEN T\&id=16245\&TreeTypelD $=4$

26. http://educapsy.com/services/formation-enseignant-surcompetence

27. https://drgawdat.edutech-portal.net/archives/15562

28. https://people.umass.edu/pelliott/reflections/ NETS-TSTANDARDS

29. https://www.new-educ.com/3- أهم استخدامات الكفايات التنريسية 